INEL-95/0145

\title{
Results of Intermediate-Scale Hot Isostatic Press Can Experiments
}

\author{
L. O. Nelson \\ K. Vinjamuri
}

Published May 1995

Idaho National Engineering Laboratory High Level Waste Immobilization Department

Lockheed Idaho Technologies Company Idaho Falls, Idaho 83415

Prepared for the

U.S. Department of Energy

Assistant Secretary for Environmental Management Under DOE Idaho Operations Office

Contract DE-AC07-94ID13223 


\section{DISCLAMMER}

This report was prepared as an account of work sponsored by an agency of the United States Government. Neither the United States Government nor any agency thereof, nor any of their employees, makes any warranty, express or implied, or assumes any legal liability or responsibility for the accuracy, completeness, or usefulness of any information, apparatus, product, or process disclosed, or represents that its use would not infringe privately owned rights. Reference herein to any specific commercial product, process, or service by trade name, trademark, manufacturer, or otherwise does not necessarily constitute or imply its endorsement, recommendation, or favoring by the United States Government or any agency thereof. The views and opinions of authors expressed herein do not necessarily state or reflect those of the United States Government or any agency thereof. 


\section{DISCLAIMER}

Portions of this document may be illegible in electronic image products. Images are produced from the best available original document. 


\section{SUMMARY}

Four intermediate-scale HIP can tests (two 6-in OD x 12-in tall and two 4-in OD x 7-in tall) are described and compared to small-scale HIP can tests (1- to 3-in OD x 1- to 4.5-in tall). The intermediate-scale HIP cans were loaded with a 70/30 calcine/frit blend and HIPped at an off-site facility at $1050^{\circ} \mathrm{C}$ and $20 \mathrm{ksi}$. The dimensions of two cans (4-in OD x 7-in tall) were monitored during the HIP cycle with eddy-current sensors. The sensor measurements indicated that can deformation occurs rapidly at $700^{\circ} \mathrm{C}$; after which, there is little additional can shrinkage.

HIP cans were subjected to a number of analyses including calculation of the overall packing efficiency (56 to 59\%), measurement of glass-ceramic density (3.0 to $3.2 \mathrm{~g} / \mathrm{cc}$ ), 14-day MCC-1 . leach testing (total mass loss rates $<1 \mathrm{~g} / \mathrm{m}^{2}$ day), and scanning electron microscopy (SEM). Based on these analyses, the glass-ceramic material produced in intermediate-scale cans is similar to material produced in small-scale cans. No major scale-up problems were indicated. Based on the packing efficiency observed in intermediate- and small-scale tests, the overall packing efficiency of production-scale (24-in OD x 36- to 180-in tall) cans would be approximately $64 \%$ for a pre-HIP right-circular cylinder geometry. An efficiency of $64 \%$ would represent a volume reduction factor of 2.5 over a candidate glass waste prepared at $33 \mathrm{wt} \%$ waste loading.

Optimization of the pre-HIP can geometry and HIP cycle would increase the HIP can overall packing efficiency. Development of a HIP can model would serve to reduce the number of experiments required to optimize the can geometry and HIP cycle. Preliminary modeling and experimental work completed in conjunction with BDM Federal has shown promise in modeling the change in HIP can geometry during the HIP cycle. Additional modeling work and HIPping of production-scale cans are recommended to design and optimize a production-scale can. Production-scale HIPs with an internal working space of 3-ft in diameter x 15-ft tall are currently used industrially in many locations and are manufactured by at least two companies. 


\section{CONTENTS}

SUMMARY $\ldots \ldots \ldots \ldots \ldots \ldots \ldots \ldots \ldots \ldots \ldots \ldots \ldots \ldots \ldots \ldots \ldots$ ii

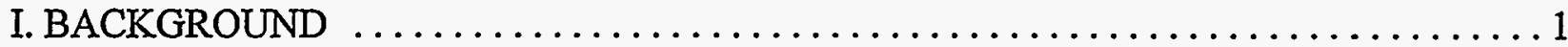

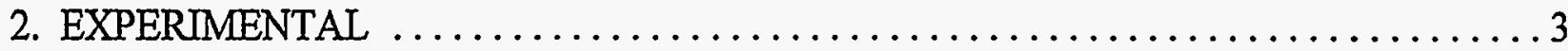

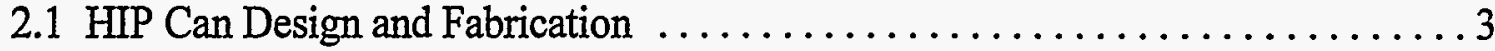

2.2 Glass-Ceramic Formulation and Powder Preparation .............. 4

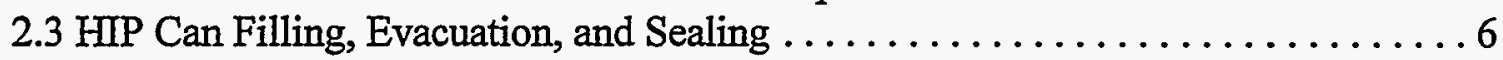

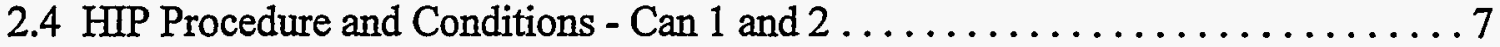

2.5 HIP Procedure and Conditions - Can 3 and $4 \ldots \ldots \ldots \ldots \ldots \ldots \ldots$

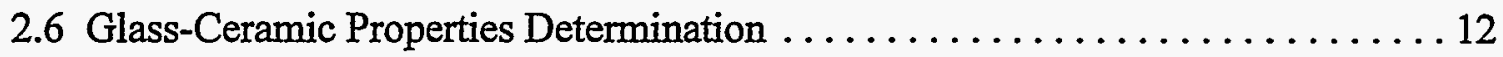

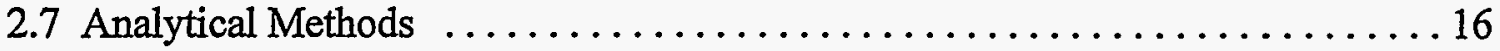

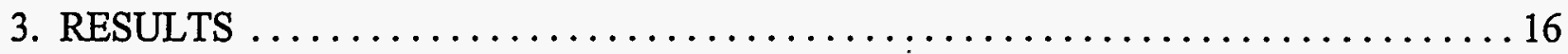

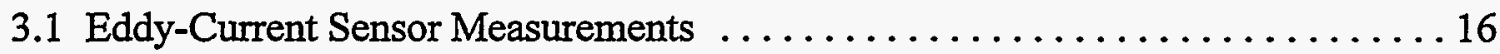

3.2 Analysis of Intact Intermediate-Scale HIP Cans $\ldots \ldots \ldots \ldots \ldots \ldots \ldots \ldots$

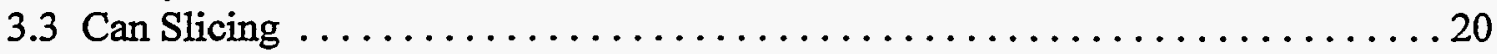

3.4 Density and MCC-1 Leach Tests Results ...................... 21

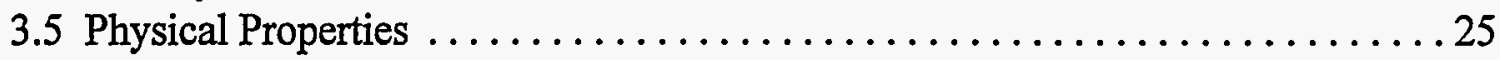

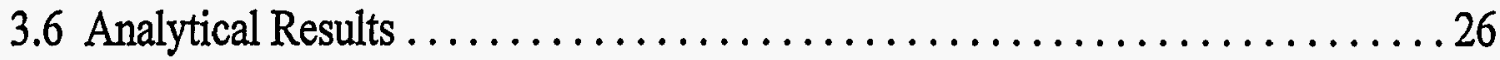

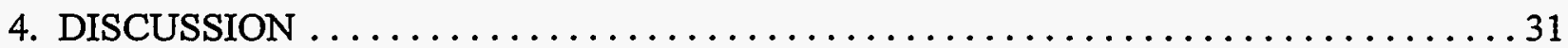

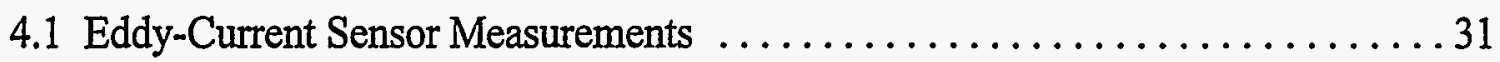

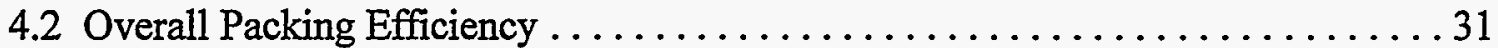

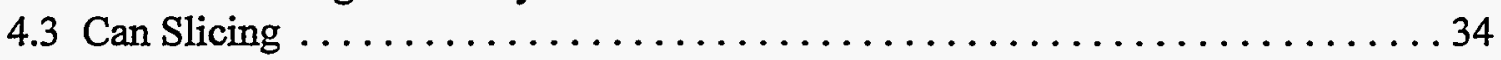

4.4 Density Measurements and $\mathrm{MCC}-1$ Leach Test $\ldots \ldots \ldots \ldots \ldots \ldots \ldots \ldots$

4.5 Physical Properties . . . . . . . . . . . . . . . . . . . . . . . . . . 35

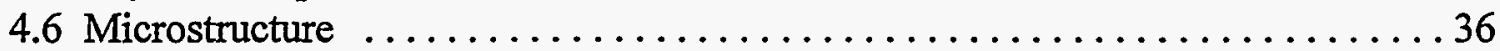

5. CONCLUSIONS AND RECOMMENDATIONS $\ldots \ldots \ldots \ldots \ldots \ldots \ldots \ldots \ldots \ldots$

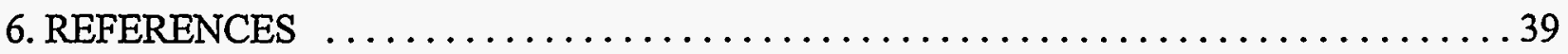




\section{LIST OF TABLES}

Table 1 Representative Chemical Composition of ICPP Calcined Wastes $\ldots \ldots \ldots \ldots \ldots 2$

Table 2 Chemical Composition of the Glass-Ceramic Formulation Used in

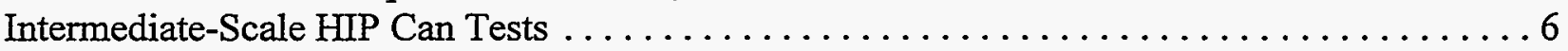

Table 3 HIP Conditions Used in Intermediate-Scale HIP Can Tests 1 and 2

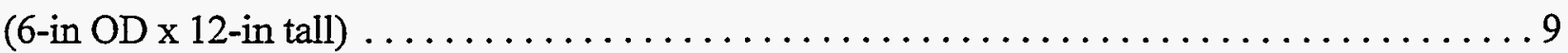

Table 4 HIP Conditions Used for $\operatorname{Can} 3 \ldots \ldots \ldots \ldots \ldots \ldots \ldots \ldots \ldots \ldots \ldots \ldots \ldots \ldots \ldots \ldots$

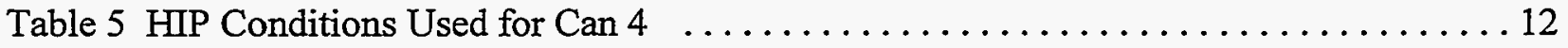

Table 6 Overall Packing Efficiency of Intermediate- and Small-Scale HIP Cans and Associated

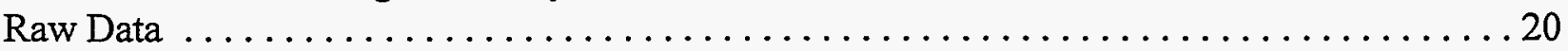

Table 7 Density ( $\rho$ ), Total Mass Loss Rate (TMLR), and Elemental Mass Loss Rate from MCC-1 Leach Tests of Samples taken from Intermediate-Scale (6-in OD x 12-in tall) HIP

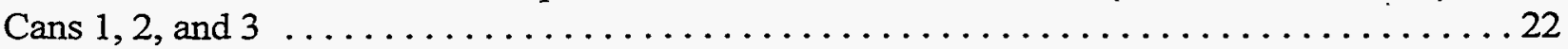

Table 8 Density ( $\rho$ ), Total Mass Loss (TMLR), and Elemental Mass Loss Rates

from MCC-1 Leach Tests of Samples Prepared in Small-Scale (1"OD x 3"tall)

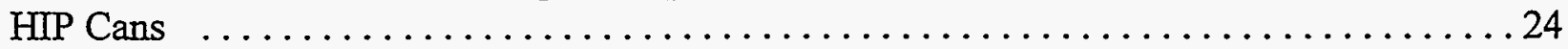

Table 9 Physical Properties of Small and Large HIP Can Glass-Ceramic Waste Forms . . . . . 25

Table 10 Elemental Composition of Glass-Ceramic Samples Taken from Can 1 . . . . . . 29 


\section{LIST OF FIGURES}

Figure 1. Schematic diagram of the hot isostatic press (HIP) can design used for intermediate-

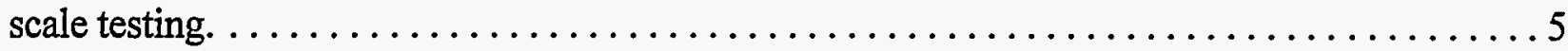

Figure 2. Schematic diagram of hot isostatic press (HIP) can placement used for intermediatescale HIP can tests completed at National Forge.. ....................... 8

Figure 3. Schematic diagram of hot isostatic press (HIP) can placement in experiments

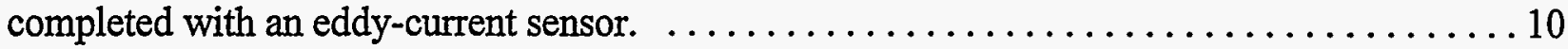

Figure 4. Schematic diagram of sample location and labeling of intermediate-scale

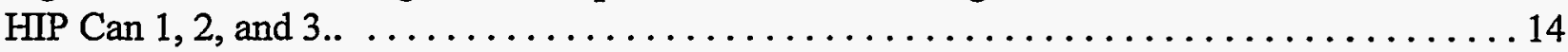

Figure 5. Schematic diagram of (a) HIP Can 3 diameter change as measured by an eddy-current

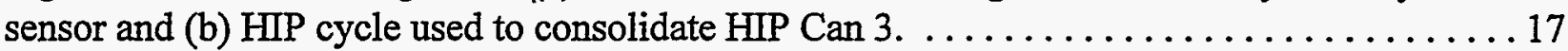

Figure 6. Schematic diagram of (a) the HIP Can 4 diameter as a function of time as measured by the eddy-current sensor and (b) the HIP cycle used to consolidate HIP Can $4 . \ldots \ldots \ldots \ldots 18$

Figure 7. Photograph of intermediate-scale HIP Can 1 and 2 (6-in OD x 12-in tall) after HIPping. . . . . . . . . . . . . . . . . . . . . . . . . . . . . 19

Figure 8. SEM micrographs of glass-ceramic samples taken from the (a) top, (b) middle, and (c) bottom of intermediate-scale (6"OD x 12" tall) Can 1. 2000X magnification. ...........27

Figure 9. SEM micrographs of glass-ceramic samples taken from the (a) top, (b) middle, and (c) bottom of intermediate-scale (6"OD x 12" tall) Can 2. 2000X magnification. . . . . . . . 28

Figure 10. Optical microscope photographs of glass-ceramic samples taken from the (a) top, (b) middle, and (c) bottom of intermediate-scale (6"OD x 12" tall) Can $1 \ldots \ldots \ldots \ldots \ldots$

Figure 11. Plot of overall packing efficiency $\left(\mathrm{E}_{\mathrm{op}}\right)$ as a function of cladding volume $\%$. The dotted line represents the expected $E_{\text {op }}$ of a can with a cladding volume of $3 \% \ldots \ldots \ldots \ldots 33$

Figure 12. ANSTO-designed HIP can. Photograph of can before and after HIPping at $1050^{\circ} \mathrm{C}$ and 20,000 psi. . . . . . . . . . . . . . . . . . . . . . . . . . . . . . . . . 33 


\section{BACKGROUND}

Radioactive high-level waste ( $\mathrm{HLW}$ ) has been managed at the Idaho Chemical Processing Plant (ICPP) for a number of years. Since 1963; liquid $\mathrm{HLW}$ has been solidified into a granular solid (calcine). Presently, over $3,800 \mathrm{~m}^{3}$ of calcine is stored in partially-underground stainless steel bins. The chemical composition of the four major calcine types is shown in Table 1.

Calcine was originally intended to be a long-term intermediate $\mathrm{HLW}$ form. However, additional calcine treatment is necessary to immobilize the radionuclides present in calcine into a leachresistant waste form suitable for disposal in a repository. Glass-ceramic, glass, and cement have been studied as potential calcine waste forms. Each of these waste forms is produced by blending calcine with additives and then processing the mixture for a specified period of time under controlled conditions. Glass-ceramic waste forms are produced from a calcine (70wt\%) and additive (30 wt\%) mixture in a hot isostatic press (HIP) at 10 to $20 \mathrm{ksi}$ and $1050^{\circ} \mathrm{C}$. Glass waste forms are produced in a glass melter from a calcine (30wt\%) and additive $(70 \mathrm{wt} \%)$ mixture at temperatures of 1000 to $1600^{\circ} \mathrm{C}$. Cementitious waste forms are produced from a calcine $(50 \mathrm{wt} \%)$ and additive $(50 \mathrm{wt} \%)$ mixture in a mixer at ambient conditions followed by a reaction period at ambient conditions, or at elevated temperatures and pressures. The waste form ultimately selected to immobilize calcine must meet several performance criteria including physical and chemical durability, corrosion resistance, and mechanical and structural properties. Chemical durability (leach resistance) as determined by the MCC-1 leach test ${ }^{1}$ is currently used to evaluate candidate waste forms.

The purpose of this report is to describe and status intermediate-scale HIP can tests (4- to 6-in OD x 7- to 12-in tall) and to compare the performance of intermediate-scale to small-scale cans. The ultimate goal of this work is to design a can which will shrink into a right-circular cylinder during HIPping. HIP can design work has been investigated over the past seven years. The scale of previous can experiments was 1 to 2 -in OD $\times 2$ - to 4 -in tall. Comparison of intermediate- to 
small-scale can performance will provide a basis to predict production-scale HIP can performance.

Table 1

Representative Chemical Composition of ICPP Calcined Wastes

\begin{tabular}{||c|c|c|c|c||}
\hline Component & Alumina & Zirconia & $\begin{array}{c}\text { Fluorinel-Na } \\
\text { Blend 4.2:1 }\end{array}$ & Zirconia-Na Blend \\
\hline $\mathrm{Al}_{2} \mathrm{O}_{3}$ & 90.0 & 14.4 & 9.6 & 14.1 \\
\hline $\mathrm{ZrO}_{2}$ & --- & 23.4 & 17.5 & 19.0 \\
\hline $\mathrm{CaF}_{2}$ & --- & 54.3 & 42.4 & 44.4 \\
\hline $\mathrm{B}_{2} \mathrm{O}_{3}$ & 0.6 & 3.0 & 2.9 & 2.5 \\
\hline $\mathrm{CdO}$ & --- & --- & 5.7 & - \\
\hline $\mathrm{Na}_{2} \mathrm{O}$ & 3.1 & --- & 5.1 & 4.5 \\
\hline $\mathrm{K}_{2} \mathrm{O}$ & --- & -- & 1.1 & 0.9 \\
\hline $\mathrm{CaO}$ & --- & 3.9 & 12.2 & 12.8 \\
\hline $\mathrm{Fe}_{2} \mathrm{O}_{3}$ & 0.6 & 0.1 & 0.2 & 0.3 \\
\hline $\mathrm{Hg}$ & 2.9 & -- & --- & -- \\
\hline $\mathrm{SO}_{4}$ & 1.2 & -- & 2.6 & 0.3 \\
\hline $\mathrm{PO}_{4}$ & --- & --- & 0.2 & 0.2 \\
\hline $\mathrm{Other}$ & --- & 1.0 & 1.0 & 1.0 \\
\hline $\mathrm{NO}_{\mathrm{x}} \& \mathrm{CO}_{\mathrm{x}}$ & 1 & 1.0 & $5-10$ & $3-8$ \\
\hline $\mathrm{Radionuclides}$ & $<1.0$ & $<1.0$ & $<1.0$ & $<1.0$ \\
\hline \hline
\end{tabular}




\section{EXPERIMENTAL}

The experiments completed in support of this work were design and fabrication of HIP cans, calcine and frit preparation, can filling and preparation, HIPping, HIPped can analysis, glassceramic sample preparation, density measurement, leach resistance measurement, scanning electron microscopy (SEM), optical microscopy, and physical properties measurement. These experiments are discussed in the following section.

\subsection{HIP Can Design and Fabrication}

A schematic diagram of the intermediate-scale HIP can design is shown in Figure 1. Four intermediate-scale cans were tested: two cans were 6-in OD x 12-in tall (Can 1 and 2) and two cans were 4-in OD $\times$ 7-in tall (Can 3 and 4). The can walls and end caps were fabricated from 0.060-in thick 304L stainless steel plate and the evacuation tube wall was fabricated from seamless 0.300 -in thick stainless steel tubing. To complete fabrication of the side walls, the plate was cut to the appropriate size, rolled to the specified diameter, and welded to form a cylinder. The end caps and evacuation tube were attached to the cylinder to complete can fabrication.

Small-scale HIP cans (1- to 2-in OD x 4- to 5-in tall) were designed and tested. The basic designs tested were straight-walled cans, wine barrel shaped cans, bellows cans, and a double wine barrel shaped can designed by the Australian Nuclear Science and Technology Organisation (ANSTO). Small-scale HIP can experiments were completed to allow determination of scale-up parameters. 


\subsection{Glass-Ceramic Formulation and Powder Preparation}

The chemical composition of two Ti-based formulations used in intermediate-scale can testing is shown in Table 2. Formulation A represents $70 \mathrm{wt} \%$ Run 17 (fluorinel-sodium) calcine blended with $30 \mathrm{wt} \%$ frit additive. Formulation B represents $35 \mathrm{wt} \%$ Run 64 (zirconia-sodium) calcine, $35 \mathrm{wt} \%$ Run 17 calcine, and $30 \mathrm{wt} \%$ frit additive. The additive consisted of $\mathrm{SiO}_{2}(22.5 \mathrm{wt} \%)$, $\mathrm{B}_{2} \mathrm{O}_{3}(2.5 \mathrm{wt} \%)$, and Ti metal powder ( $5 \mathrm{wt} \%-<300$ mesh). The Ti-based formulation was developed and recommended for intermediate-scale testing by the ICPP waste form chemistry group. This formulation appears to be relatively insensitive to process variations (e.g., quality of mixing, particle size, and precise waste loadings ${ }^{2}$ ) as compared to other candidate glass-ceramic formulations.

Run 17 calcine product and fines was heat treated for 30 hours at $600^{\circ} \mathrm{C}$ to volatilize residual $\mathrm{NO}_{x}, \mathrm{CO}_{x}$, and $\mathrm{H}_{2} \mathrm{O}$ and the additive was heat-treated at $1000^{\circ} \mathrm{C}$ prior to calcine/frit blending. Run 64 calcine was not heat treated. Next, Run 17 and Run 64 calcine product was ground to less than 80 mesh and combined with calcine fines in a 4:1 weight ratio to simulate actual HLW calcine stored in the bin sets. Next, calcine and frit were combined in glass jars and tumbled for 30 minutes to obtain a homogeneous blend. Last, the calcine/frit mixture was packaged in DOT 15A containers and shipped to an off-site toll HIP vendor. 


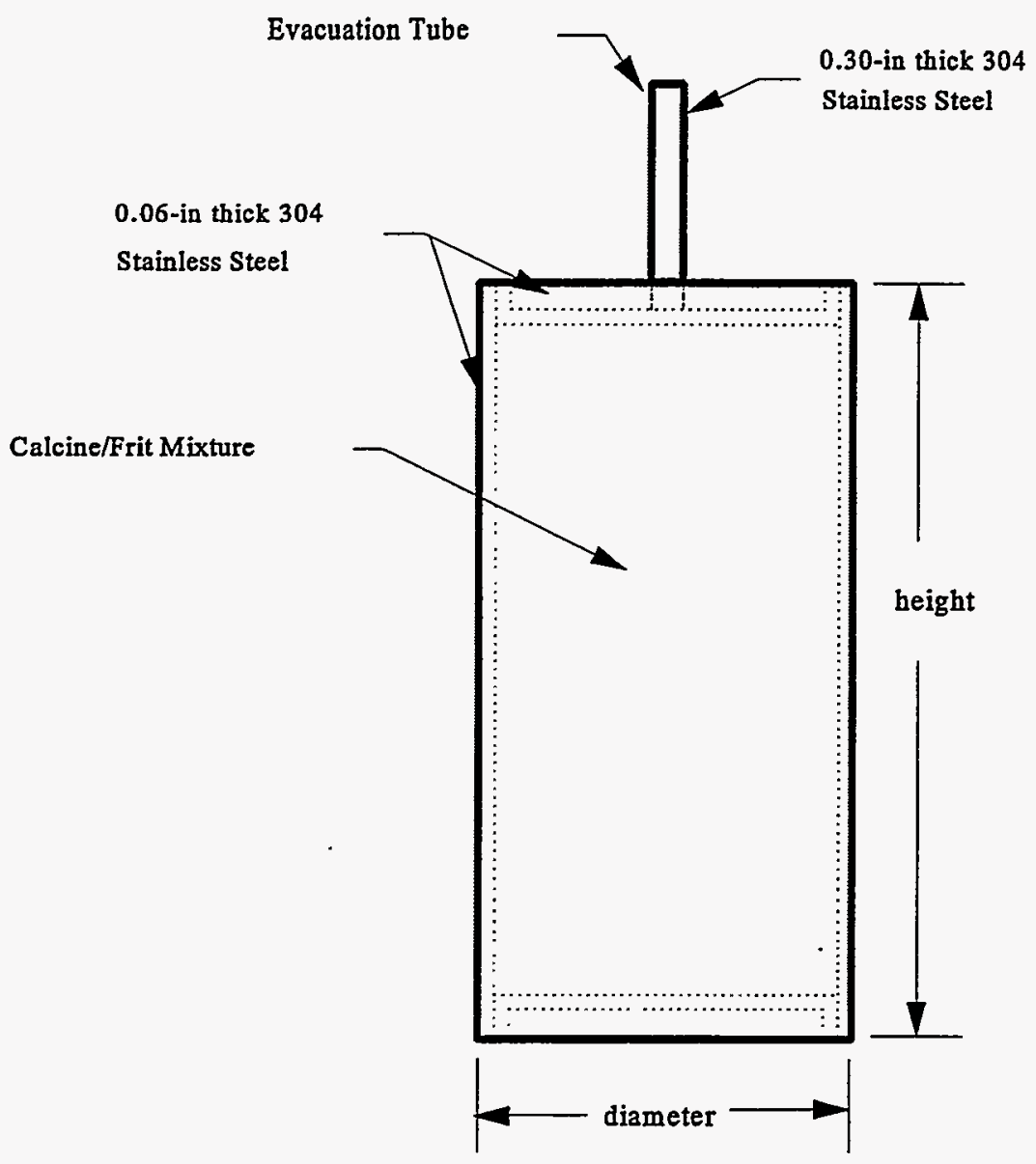

Figure 1. Schematic diagram of the hot isostatic press (HIP) can design used for intermediatescale testing. 
Table 2

Chemical Composition of the Glass-Ceramic Formulation Used in

Intermediate-Scale HIP Can Tests

\begin{tabular}{||c|c|c||}
\hline \hline Component & Formulation A (wt\%) & Formulation B (wt\%) \\
\hline \hline $\mathrm{Al}_{2} \mathrm{O}_{3}$ & 10.5 & 8.3 \\
\hline $\mathrm{B}_{2} \mathrm{O}_{3}$ & 2.5 & 3.6 \\
\hline $\mathrm{CaO}$ & 9.7 & 7.2 \\
\hline $\mathrm{CdO}$ & 2.1 & 4.1 \\
\hline $\mathrm{Cr}_{2} \mathrm{O}_{3}$ & 0.8 & 1.1 \\
\hline $\mathrm{CaF}_{2}$ & 27.4 & 28.0 \\
\hline $\mathrm{Fe}_{2} \mathrm{O}_{3}$ & 0.2 & 0.4 \\
\hline $\mathrm{K}_{2} \mathrm{O}$ & 0.7 & 0.8 \\
\hline $\mathrm{MnO}_{2}$ & 0.1 & 0.2 \\
\hline $\mathrm{Na}_{2} \mathrm{O}$ & 3.0 & 3.7 \\
\hline $\mathrm{NiO}_{\mathrm{SiO}}$ & 0.1 & 0.2 \\
\hline $\mathrm{SrO}$ & 0.1 \\
\hline $\mathrm{ZrO}$ & 0.1 & 13.8 \\
\hline $\mathrm{SiO}$ & 14.0 & 23.8 \\
\hline $\mathrm{Ti}$ & 23.8 & 5.0 \\
\hline \hline $\mathrm{Total}$ & 5.0 & 100 \\
\hline \hline
\end{tabular}

\subsection{HIP Can Filling, Evacuation, and Sealing}

The calcine/frit mixture was added to the HIP can before the top was welded to the can side walls. The can was placed on a manually-operated vibrating table during filling to maximize the packing density of the calcine/frit mixture. Intermittent can vibration was used to avoid calcine/frit mixture segregation. Manual tamping of the can during the filling operation did not increase the packing density. Cans were filled to $1 / 2$-in below the top of the can side walls with 
the calcine/frit mixture, the can side walls were recleaned, and the top and evacuation tube were welded in place (see Figure 1) to complete can preparation.

The evacuation tube was filled to a height of approximately two inches with the calcine/frit mixture once the top and evacuation tube were welded in place. Next, steel wool was packed into the evacuation tube to clean the inner walls of the tube and to prevent powder loss during evacuation. The height of steel wool in the tube after packing was marked for reference during crimping. The cans were evacuated to $<50 \mu \mathrm{m} \mathrm{Hg}$ and attached to a helium leak detector to test all of the weld joints.

Next, the cans were placed in a bake-out furnace under a dynamic vacuum. A bake-out temperature of $600^{\circ} \mathrm{C}$ and vacuum level of less than $50 \mu \mathrm{m}$ were specified for Can 1 and 2 to remove residual volatile species $\left(\mathrm{NO}_{x}, \mathrm{CO}_{x}\right.$, and $\left.\mathrm{H}_{2} \mathrm{O}\right)$ from unheat-treated calcine. A bake-out temperature of $350^{\circ} \mathrm{C}$ and vacuum level of less than $50 \mu \mathrm{m}$ were specified for Can 3 and 4 to remove residual $\mathrm{H}_{2} \mathrm{O}$. Vacuum bake out of $\mathrm{Can} 1$ and 2 required 36 hours. Bake out of $\mathrm{Can} 3$ and 4 required 2 hours. The evacuation tubes were crimped and sealed (under vacuum) once the required vacuum level was attained. The excess fill tubing was removed and the tube ends were tungsten inert gas (TIG) welded. ${ }^{3}$

\subsection{HIP Procedure and Conditions - Can 1 and 2}

HIP Can 1 and 2 (Can 1 was filled with Formulation A and Can 2 was filled with Formulation B - see Table 2) were placed side-by-side in a 16-in OD HIP chamber with an overhead crane. A schematic diagram of the can placement is shown in Figure 2. The HIP conditions are shown in Table 3. 


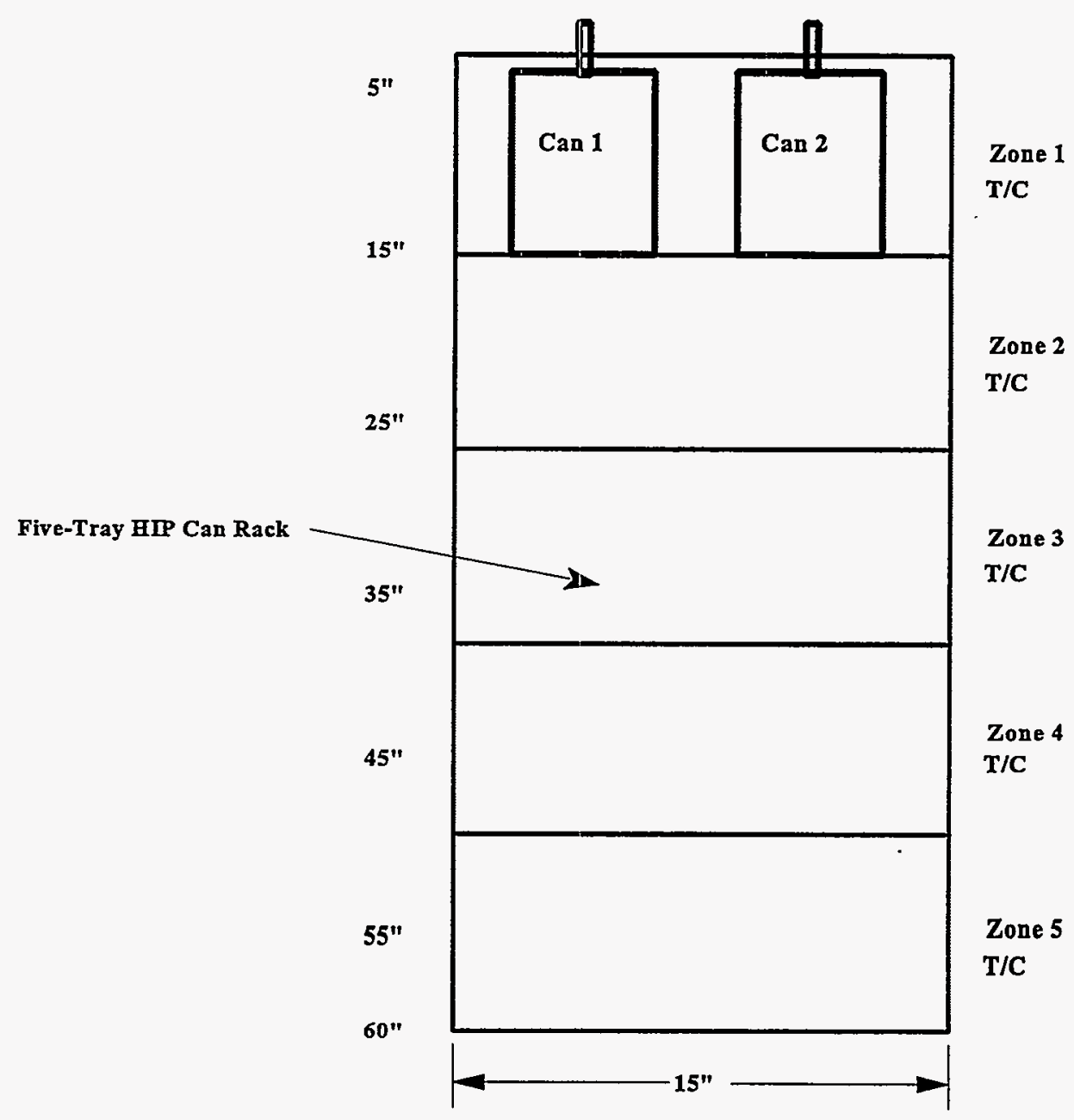

Figure 2. Schematic diagram of hot isostatic press (HIP) Can 1 and 2 placement used for intermediate-scale HIP can tests completed at National Forge. The cans were placed on the top tray in a five-tray HIP can rack. 
Table 3

HIP Conditions Used in Intermediate-Scale

HIP Can Tests 1 and 2 (6-in OD x 12-in tall)

\begin{tabular}{||l|l||}
\hline HIP Condition & Operating Level \\
\hline \hline Initial Temperature Setpoint & $1050^{\circ} \mathrm{C} \pm 10^{\circ} \mathrm{C}$ \\
\hline Heat-up Time to Reach Soak Temperature & 300 minutes \\
\hline Soak Temperature & $1050^{\circ} \mathrm{C}$ \\
\hline Densification Pressure & $20,000 \mathrm{psi}$ \\
\hline Soak Time & 245 minutes \\
\hline Final Temperature Setpoint & $250^{\circ} \mathrm{C}$ \\
\hline Cool-Down Time & 450 minutes \\
\hline Pressurizing Gas & Argon \\
\hline
\end{tabular}

\subsection{HIP Procedure and Conditions - Can 3 and 4}

Can 3 and 4 (both cans were filled with Formulation A - see Table 2) were placed in a Crucible Engineers' HIP surrounded by an eddy-current sensor as shown in Figure 3. The sensor consisted of two coils: a primary coil to which an electrical excitation or stimulus was applied, and a secondary coil which was concentrically aligned to the interior of the primary coil and which picked up an electrical response. ${ }^{4}$ The stimulus (primary)-response (secondary) pair was used to calculate a frequency-dependent impedance curve. The normalized impedance curve was used to obtain reliable estimates of the sample diameter and glass-ceramic material density during HIPping. 


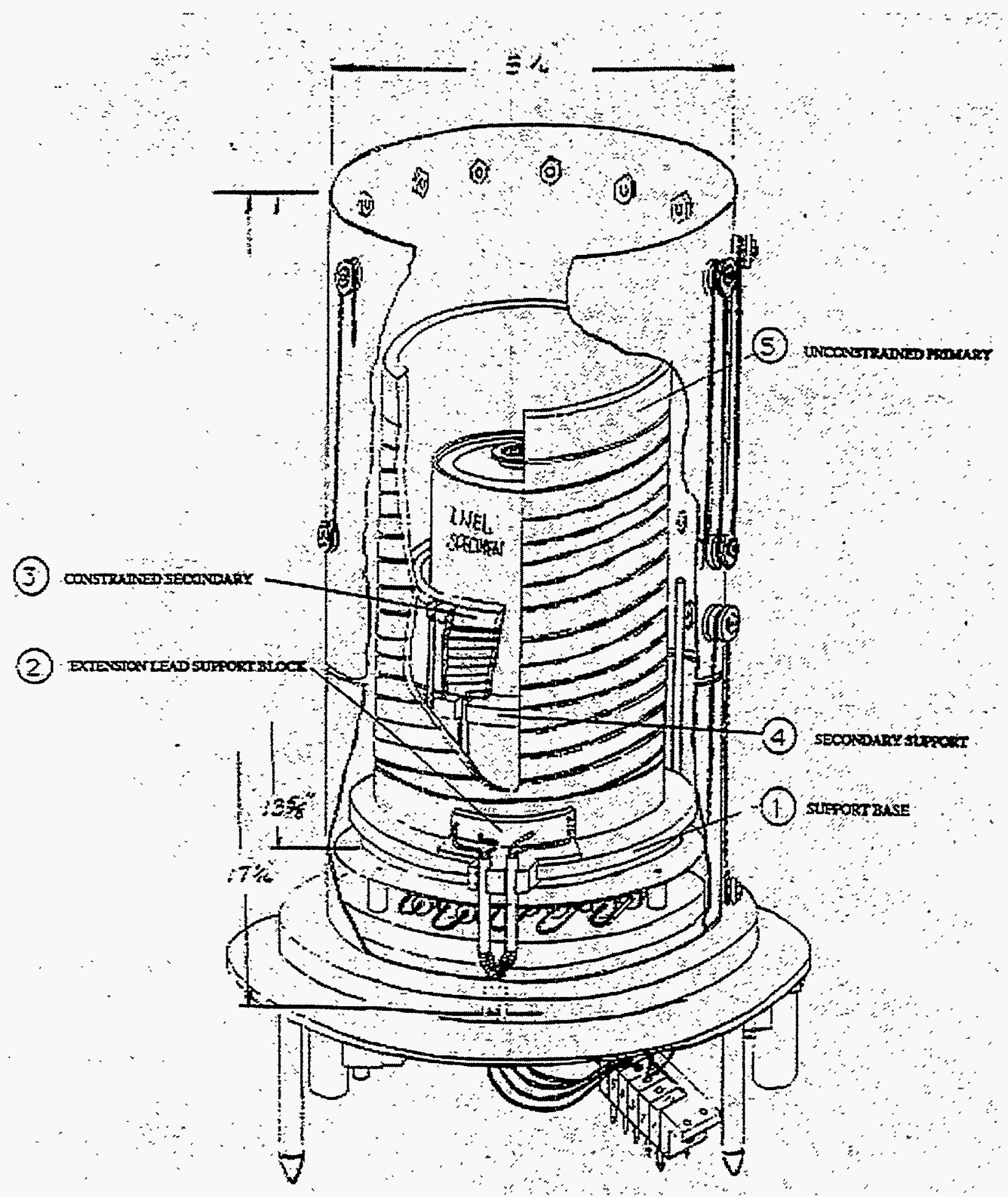

Figure 3. Schematic diagram of hot isostatic press (HIP) can placement in experiments completed with an eddy-current sensor. The eddy-current sensor consisted of a primary coil (5), a secondary coil (3), and various support structures $(1,2$, and 4). The HIP can is labeled "INEL SPECIMEN." 
The HIP cycle and conditions used for Can 3 and 4 are shown in Table 4 and 5 respectively. Can 3 was partially densified to $65 \%$ of theoretical density prior to full densification to ensure that the eddy-current sensor was operating properly and that the HIP can would not fail. Can 3 was fully densified at $1050^{\circ} \mathrm{C}$ and 20,000 psi after the partial densification HIP cycle. Can 4 was HIPped at $950^{\circ} \mathrm{C}$ and 20,000 psi.

Table 4

HIP Conditions Used for Can 3

\begin{tabular}{||l|l|l||}
\hline HIP Condition & $\begin{array}{l}\text { Partial Densification } \\
\text { Operating Level }\end{array}$ & $\begin{array}{l}\text { Final Densification Operating } \\
\text { Level }\end{array}$ \\
\hline Soak Temperature & $550^{\circ} \mathrm{C}$ & $1050^{\circ} \mathrm{C}$ \\
\hline $\begin{array}{l}\text { Heat-Up Time to Reach Soak } \\
\text { Temperature }\end{array}$ & 60 minutes & 240 minutes \\
\hline Soak Pressure & 6,000 psi & 20,000 psi \\
\hline Soak Time & 5 minutes & 45 minutes \\
\hline Cool-Down Time & 170 minutes & 300 minutes \\
\hline Pressurizing Gas & Argon & Argon \\
\hline
\end{tabular}


Table 5

HIP Conditions Used for Can 4

\begin{tabular}{||l|l||}
\hline HIP Condition & Operating Level \\
\hline Soak Temperature & $950^{\circ} \mathrm{C}$ \\
\hline Heat-Up Time to Reach Soak Temperature & 200 minutes \\
\hline Soak Pressure & 20,000 psi \\
\hline Soak Time & 40 minutes \\
\hline Cool-Down Time & 180 minutes \\
\hline Pressurizing Gas & Argon \\
\hline \hline
\end{tabular}

\subsection{Glass-Ceramic Properties Determination}

HIPped cans were returned to the ICPP for the following tests: $\mathrm{x}$-ray analysis to detect cracks, average glass-ceramic density determination via Archimedes principal, and calculation of the overall packing efficiency. Next, the can was sliced to produce monolithic glass-ceramic samples. Last, the monolithic samples were subjected to density measurements, physical properties estimation, and $\mathrm{MCC}-1$ leach testing.

The glass-ceramic characterization data collected on monolithic samples (i.e., MCC-1 leach test results and density) were subjected to the Shapiro-Wilke statistical test. ${ }^{5}$ The purpose of the Shapiro-Wilke test was to determine if the experimental data were normally distributed. A normal distribution would infer that differences between data are due to experimental error and not to an underlying mechanism. For example, the data are normally distributed if the ' $W$ ' statistic calculated for a sample set of nine and a confidence level of $95 \%$ is greater than 0.829 (see Reference 4, Table 6). 
The overall packing efficiency, $E_{o p}$, was calculated for each HIP can using the following equation:

$$
E_{o p}=\frac{\text { Mass of Glass -Ceramic in Can }}{\pi *(\text { Can Radius })^{2} *(\text { Can Height }) * 3.2 \mathrm{~g} / \mathrm{cc}} * 100 \%
$$

where $3.2 \mathrm{~g} / \mathrm{cc}$ is the reference glass-ceramic density. The goal of HIP can development is to produce a right circular cylinder glass-ceramic monolith $\left(E_{o p}=100 \%\right)$. Experimentally demonstrated values (small-scale cans) for the $\mathrm{E}_{\mathrm{op}}$ have ranged from 40 to $75 \%$. An additional value of interest to HIP can development is the volume reduction factor, VRF, of cans filled with glass-ceramic compared to glass. The VRF is calculated from

$$
V R F=\frac{\text { Glass Ceramic } E_{O P} * 70 w t \% \text { loading } * 3.2 \mathrm{~g} / \mathrm{cc}}{\text { Glass } E_{o p} * 33 w t \% \text { Loading } * 2.6 \mathrm{~g} / \mathrm{cc}}
$$

where Glass-Ceramic $E_{o p}$ is the $E_{o p}$ calculated for the HIP can of interest, $70 \mathrm{wt} \%$ is the calcine loading in the glass-ceramic, $3.2 \mathrm{~g} / \mathrm{cc}$ is the reference glass-ceramic density, Glass $\mathrm{E}_{\mathrm{op}}$ is the $\mathrm{E}_{\mathrm{op}}$ calculated for the reference glass $\mathrm{can}^{6}(70 \%), 33 \mathrm{wt} \%$ is the calcine loading in the glass, and the reference glass density is $2.6 \mathrm{~g} / \mathrm{cc}$.

The cans were sliced using a Brook Crompton saw equipped with an 8" diameter cubic boron nitride blade. A schematic diagram of the sliced HIP cans and the glass-ceramic sample labeling scheme is shown in Figure 4. Three monolithic $\left(1 \mathrm{~cm}^{3}\right)$ samples were taken at the top, middle, and bottom of each can (9 samples from each can). The samples were labeled C1T1, C1T2, C1T3 for the top of Can 1; C1M1, C1M2, C1M3 for the middle of can 1; and C1B1, C1B2, $\mathrm{C} 1 \mathrm{~B} 3$ for the bottom of Can 1. A similar labeling scheme was used for Can 2: C2T1, C2T2, .., C2B3. Larger sample bars. $\left(1 " \times 0.25^{\prime \prime} \times 4 "\right)$ were taken from each can (3 samples from each can - labeled C1T, C1M, and C1B for can 1 and C2T, C2M, and C2B for can 2) to obtain estimates of the material properties (see Figure 4 for sample bar labeling). Can 1 and 3 sample bars were 
taken from the middle to the edge of each slice. Can 2 sample bars were taken axially as shown in Figure 4.
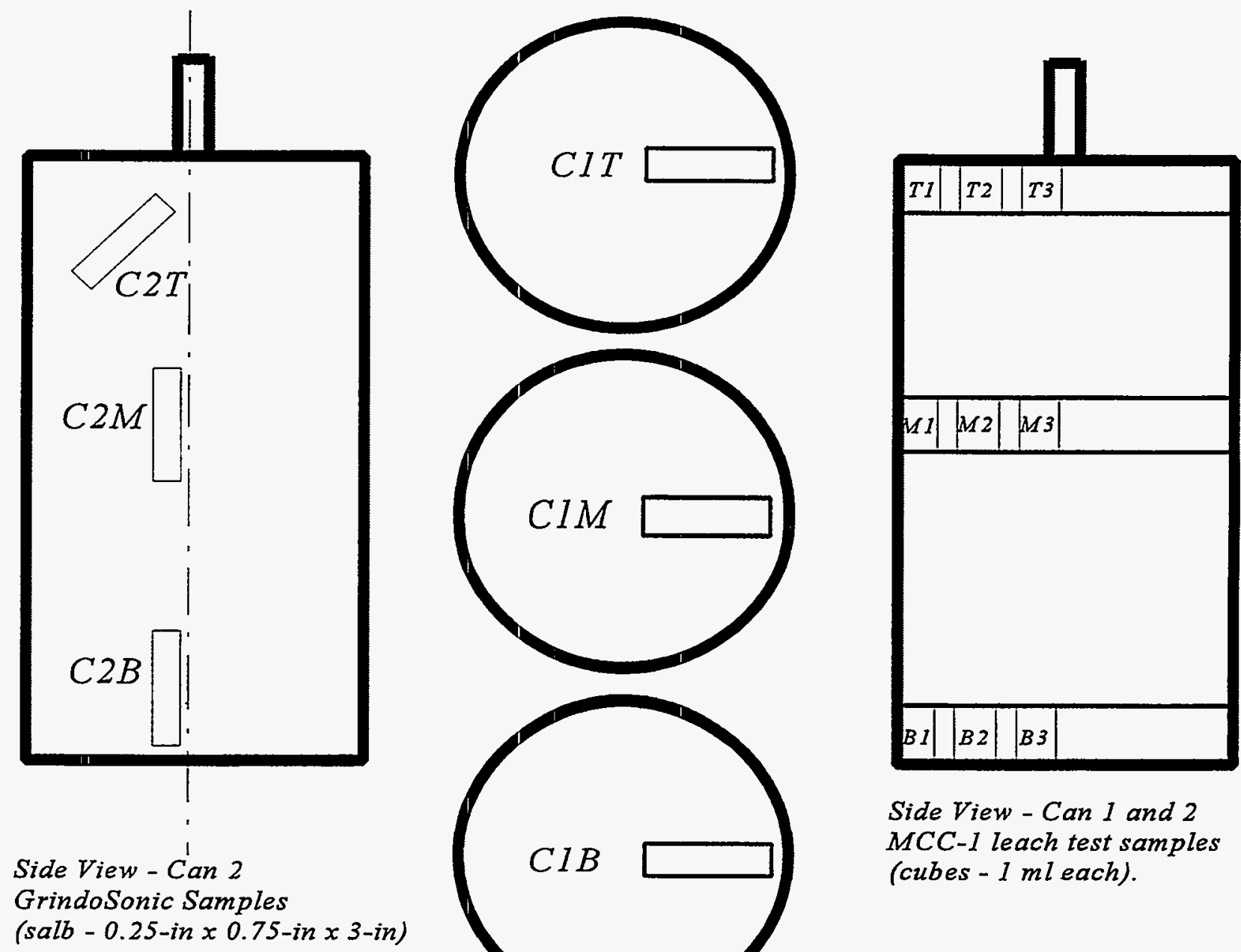

Side View - Can 1 and 2 $M C C-1$ leach test samples (cubes - I ml each).

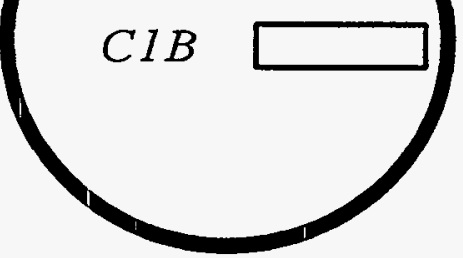

Top View - Can I

GrindoSonic Samples

(slabs - 0.25-in $\times 0.75$-in $\times 3$-in)

Figure 4. Schematic diagram of sample location and labelling of intermediate-scale HIP Can 1, 2 , and 3.

The density of the glass-ceramic monolithic samples was measured using a Micromiretics model Accupyc 1330 pycnometer, the physical properties were measured using a GrindoSonic model $\mathrm{MK} 5$, and 14-day MCC-1 leach testing were completed in distilled water at $90^{\circ} \mathrm{C} .{ }^{1}$ Estimation 
of glass-ceramic physical properties was done non-destructively with a bench-top GrindoSonic instrument. Physical properties were estimated by the GrindoSonic instrument based on the longitudinal, flexural, and torsional frequencies resulting from a small tap on the glass-ceramic sample bar. The Young's modulus, E, was calculated from the equation

$$
E=2 G(1+v)=\frac{\sigma}{\epsilon}
$$

where $G=$ shear modulus, $v=$ Poisson's ratio, $\sigma=$ stress, and $\epsilon=$ strain.

The Young's modulus represents the proportionality constant between stress and strain $(E=\sigma / \epsilon)$. General trends between the Young's modulus and other material properties have been identified. For example, the Young's modulus is inversely proportional to the thermal expansion coefficient, whereas the "strength" of the material is directly proportional to the Young's modulus. Typical room temperature values of the Young's modulus for quartz (similar to glass-ceramic) and diamond are 10 and 114 mpsi respectively.

To complete measurements with the GrindoSonic, an attached microphone or probe senses the vibrations resulting from a simple tap on the solid sample of interest. The background noise and harmonics are filtered out and the fundamental resonant frequency is displayed on the instrument readout. A computer program is used to calculate $G$ and $v$ from the resonant frequency displayed on the instrument, sample dimensions, mass, and geometry. The physical properties estimated with the Grindosonic instrument are very accurate unless the sample of interest is cracked. Hence, the physical properties of cracked samples must be determined by other means.

Glass-ceramic monoliths were prepared from small-scale (1-in OD x 3-in tall) cans for scale-up comparison purposes. Small-scale HIP cans (1"OD x $3 "$ tall) are typically sliced radially to produce discs. Next, these disks are sliced into monolithic samples for MCC-1 leach testing, physical property measurements, and density measurements. The properties of glass-ceramic 
material produced in small-scale cans are presented and compared to the properties of material produced in intermediate-scale HIP can tests

\subsection{Analytical Methods}

Glass-ceramic samples produced via HIP are routinely analyzed using scanning electron microscopy (SEM) and optical microscopy to determine crystalline phases present, glass phase composition, and overall microscopic structure. Samples of glass-ceramic material produced in intermediate-scale tests were subjected to these analyses and compared to material produced in previously-completed small-scale tests. The SEM utilized was an Amray model 1830 co-located with a Kevex model Delta 5 energy dispersive spectrometer (EDS). The optical microscope was a Zeiss Petrographic microscope. A limited amount of work was completed on a superprobe model JEOL 8600.

\section{RESULTS}

The results of intermediate-scale HIP can tests are presented below. Results include eddycurrent sensor measurements, visual inspection of intact HIP cans, $\mathrm{x}$-ray inspection of intact HIP cans to detect cracks in the glass-ceramic material before slicing, calculation of the overall packing efficiency, can slicing, glass-ceramic sample density, MCC-1 leach tests, SEM, optical microscopy, and physical properties measurements.

\subsection{Eddy-Current Sensor Measurements}

The dimensional change of Can 3 and 4 was measured during the HIP cycle with an eddy-current sensor developed by BDM.Federal. The measurements taken with the sensor are shown in Figure 5 and 6 for Can 3 and 4 respectively. The can dimensions are relatively constant until approximately $700^{\circ} \mathrm{C}$ when they decrease rapidly. At temperatures above $750^{\circ} \mathrm{C}$, the dimensions decrease slowly until the experiment is terminated. 


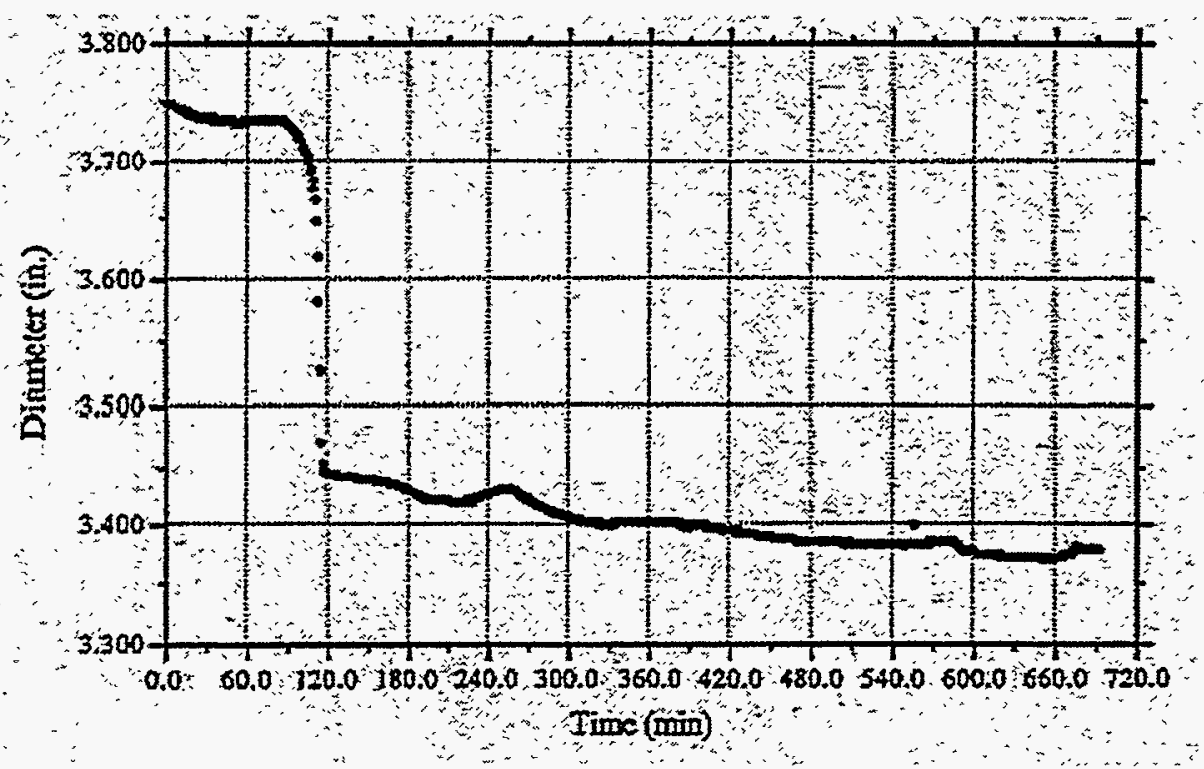

(a)

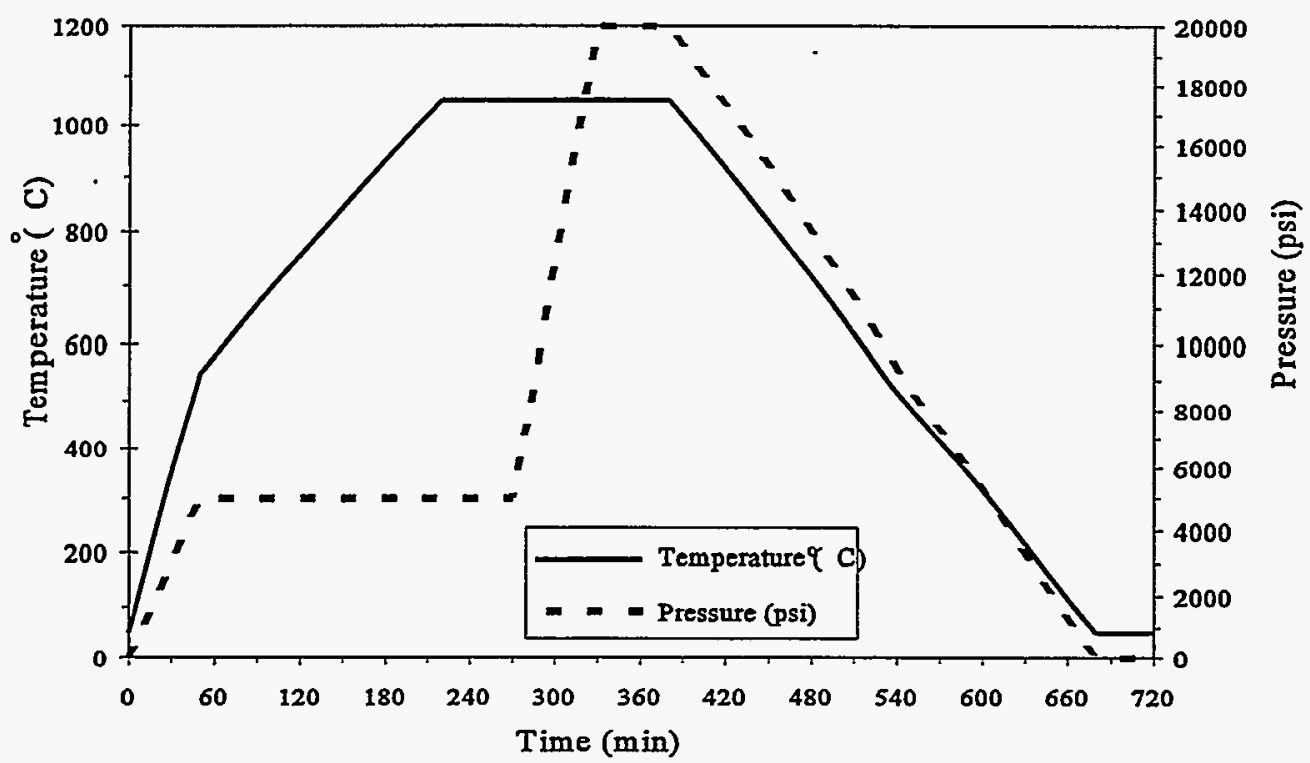

(b)

Figure 5. Schematic diagram of (a) HIP Can 3 diameter change as measured by an eddy-current sensor and (b) the HIP cycle used to consolidate Can 3 . 


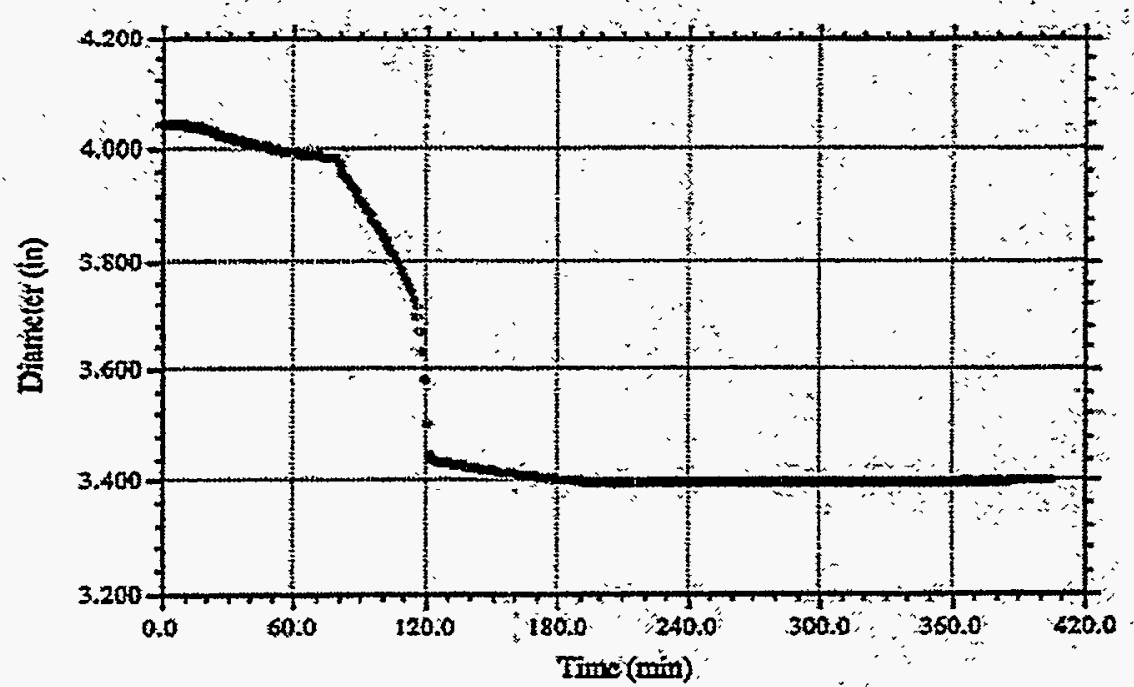

(a)

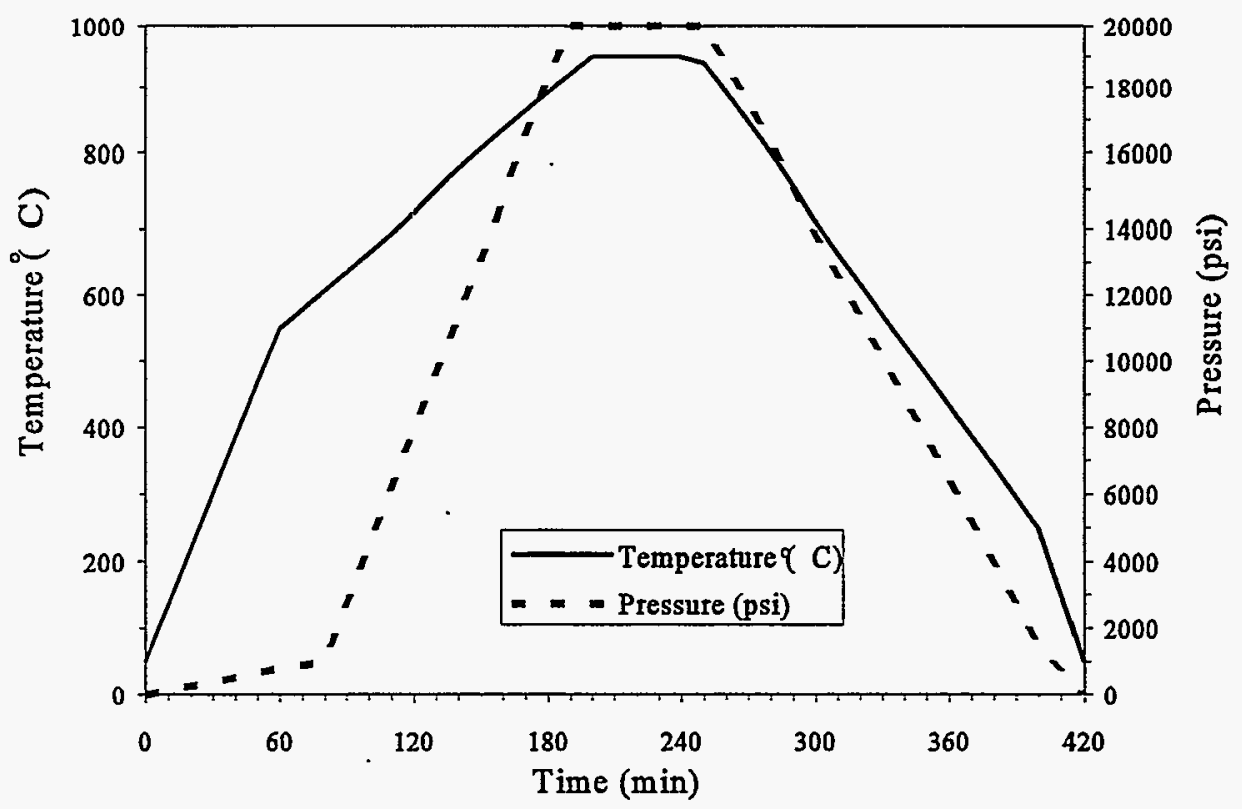

(b)

Figure 6. Schematic diagram of (a) the HIP Can 4 diameter as a function of time as measured by the eddy-current sensor and (b) the HIP cycle used to consolidate Can 4. 


\subsection{Analysis of Intact Intermediate-Scale HIP Cans}

A photograph of HIP Can 1 and 2 (6-in OD x 12-in tall) is shown in Figure 7. Deformation of the cans was similar to deformation observed in small-scale HIP cans. The can top, bottom and side walls were bowed toward the center and the can edges remained more or less in place. Can 3 and 4 behaved similarly with the exception of the stiff seam weld in the can side walls. The stiff seam resisted deformation and did not allow the can length to decrease during the HIP cycle. As a result, $C a n 3$ and 4 exhibited a lower $E_{o p}$. The pertinent raw data and the $E_{o p}$ (see Equation 1) for intermediate-scale HIP cans and a reference small-scale HIP can is shown in Table 6. The $\mathrm{E}_{\mathrm{op}}$ is approximately 13 to $14 \%$ higher for Can 1 and 2 as compared to similarly-configured small-scale cans.

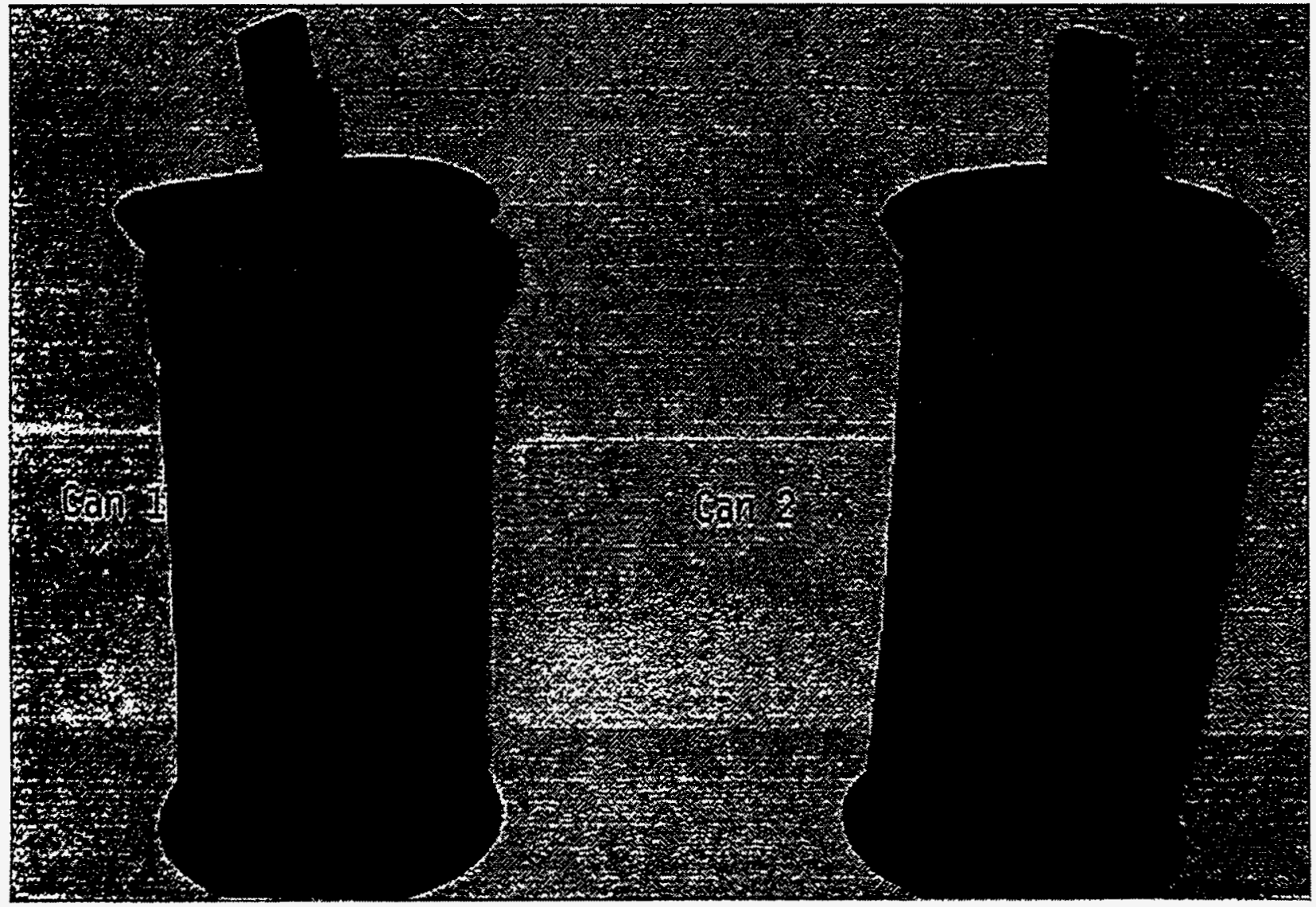

Figure 7. Photograph of intermediate-scale Can 1 and 2 (6-in OD $\times 12$-in tall) after HIPping. 
Table 6

Overall Packing Efficiency of Intermediate- and Small-Scale HIP Cans and Associated Raw Data

\begin{tabular}{|c|c|c|c|c|c|}
\hline Property & Can 1 & Can 2 & Can 3 & Can 4 & $\begin{array}{l}\text { Small-Scale } \\
\text { Test }^{7}\end{array}$ \\
\hline Approximate Green Density (g/cc) & 1.73 & 1.78 & 1.65 & 1.65 & 1.62 \\
\hline Diameter (inches) & 6.05 & 6.05 & 4.02 & 4.02 & 1.01 \\
\hline Height (inches) & 11.24 & 11.20 & 7.27 & 7.27 & 2.89 \\
\hline Mass of Empty Can in Air (g) & 3,152 & 3,168 & 1,300 & 1,200 & 60.6 \\
\hline Mass of Full Can in Air (g) & 12,769 & 13,073 & 3,486 & 3,386 & 114.3 \\
\hline Mass of Glass-Ceramic (g) & 9,617 & 9,905 & 2,186 & 2,186 & 53.7 \\
\hline $\begin{array}{l}\text { Mass of Can + Glass-Ceramic in } \\
\mathrm{H}_{2} \mathrm{O}(\mathrm{g})\end{array}$ & 8,705 & 9,003 & 2,594 & 2,501 & $-\cdots$ \\
\hline $\begin{array}{l}\text { Volume of Can - Glass-Ceramic } \\
\text { Material (ml) }\end{array}$ & 3,351 & 3,473 & 892 & 885 & --- \\
\hline Volume of Can Cladding (ml) & 304 & 320 & 158 & 149 & $-\ldots$ \\
\hline Volume of Glass-Ceramic (ml) & 3,047 & 3,153 & 734 & 736 & --- \\
\hline VRF & 2.12 & 2.18 & 1.68 & 1.68 & 1.65 \\
\hline $\begin{array}{l}\text { Average Glass-Ceramic Density } \\
(\mathrm{g} / \mathrm{cc})\end{array}$ & 3.00 & 3.14 & 3.0 & 3.0 & 3.16 \\
\hline$E_{o p}(\%)$ & 56.8 & 58.5 & 45 & 45 & 44.3 \\
\hline
\end{tabular}

\subsection{Can Slicing}

Can 1 and 3 were cut into three major pieces: a $1 \mathrm{~cm}$-thick slice from the can top, middle, and bottom. Cracking was observed in all three slices. This cracking prevented taking samples larger than three to four inches long. A sulfur smell was noted while can 1 was sliced which indicated the presence of volatile sulfur compounds (most likely sulfur dioxide) in the waste 
form. However, excessive internal can pressure was not noted. Sulfur was not detected in the ambient air during the Can 2 and 3 slicing operation indicating that the formulation used in Can 2 and 3 had immobilized the sulfur.

\subsection{Density and MCC-1 Leach Tests Results}

The density of monolithic $\left(1 \mathrm{~cm}^{3}\right)$ samples taken from Can 1,2, and 3 was measured in a Micromiretics pycnometer prior to MCC-1 leach testing. The density of each sample is shown in Table 7. The glass-ceramic density ranged from 3.08 to $3.34 \mathrm{~g} / \mathrm{cc}$. This density range is typical for Ti-based glass-ceramic waste formulations. The average density of monolithic samples taken from Can 1,2 , and 3 was $3.14 \pm 0.08,3.16 \pm 0.08$, and $3.12 \pm 0.09$ respectively.

The total and normalized elemental leach rates observed during 14-day MCC-1 leach tests are shown in Table 7 for Can 1 and 2. Glass-ceramic samples produced in Cans 3 and 4 were not subjected to the MCC-1 leach testing procedure. However, the total mass loss rate of samples taken from Can 3 were estimated using the LCT test. The total mass loss rate and most of the normalized elemental leach rates for samples taken from Can 1 and 2 are below $1 \mathrm{~g} / \mathrm{m}^{2}$-day. The leach rate for silicon and several other minor calcine components $(\mathrm{B}, \mathrm{Cd}, \mathrm{K}$, and $\mathrm{Na}$ ) exceed 1 $\mathrm{g} / \mathrm{m}^{2}$ day. Based on the Shapiro-Wilke test, $(\mathrm{W}>0.829)$ the data were normally distributed and as a result, small variances in the data are due to experimental error (spectrochemical analyses have an uncertainty of $10 \%)$. Where data sets have large variances, underlying mechanisms could be suspected. For example, a large variance in the elemental mass loss rate for species that typically are found in the glass phase $(\mathrm{Al}, \mathrm{B}, \mathrm{K}, \mathrm{Na}$, and $\mathrm{Si})$ and for $\mathrm{Cd}$ could be due to an underlying mechanism. However, the small variance in the elemental mass loss rate for $\mathrm{Ca}$ (which normally occurs in the crystalline phase) likely is due to experimental uncertainty. Results from previous small-scale waste form experiments completed under similar HIPping conditions are shown in Table 8 for comparison purposes. 


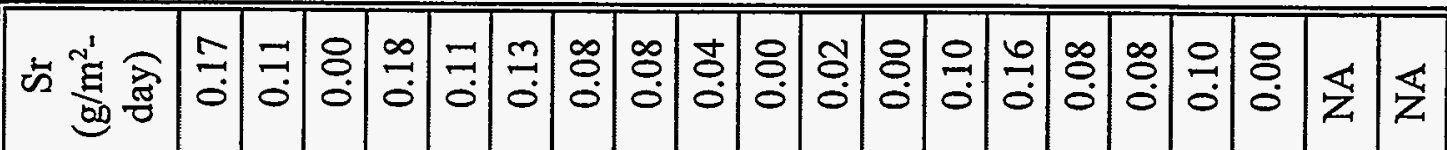
क्ष

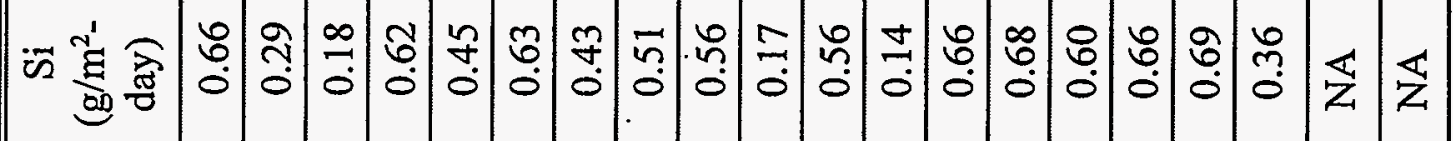

iी

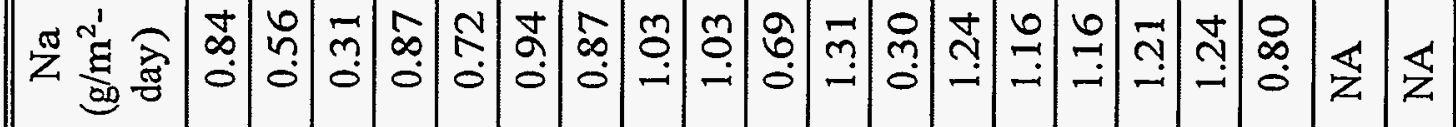
.

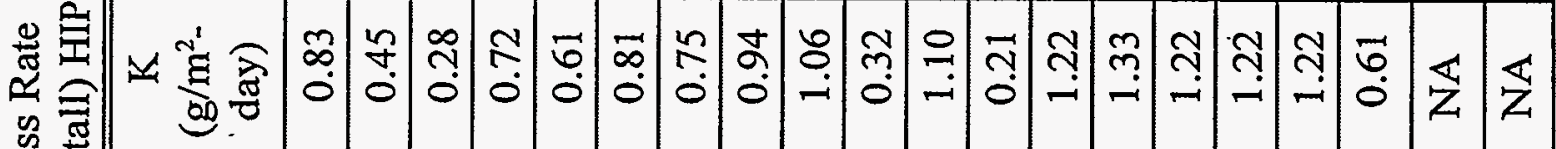
o

出

U 占

픙

छ.

당

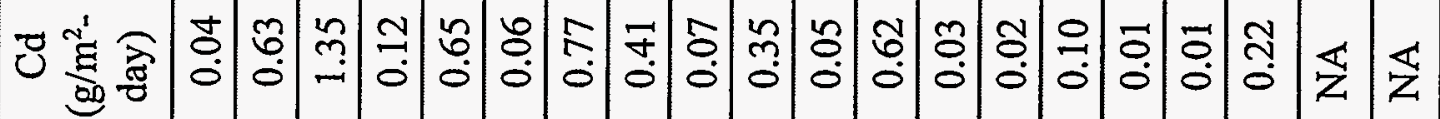
7

政

$\sim$.

$\frac{0}{2}$

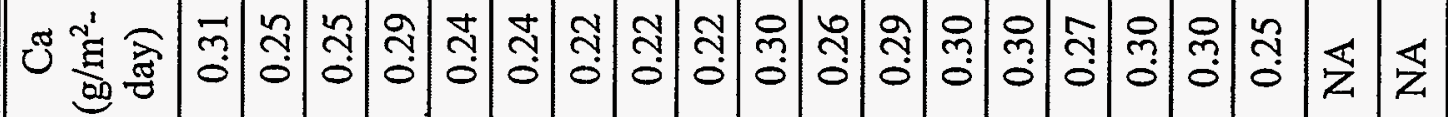

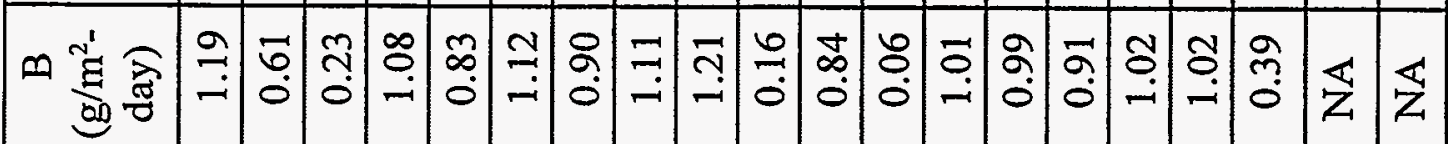

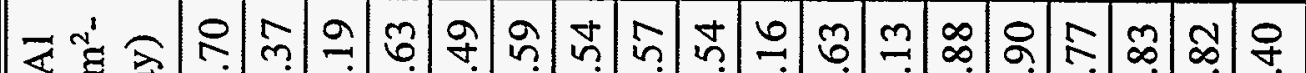

(2)

중

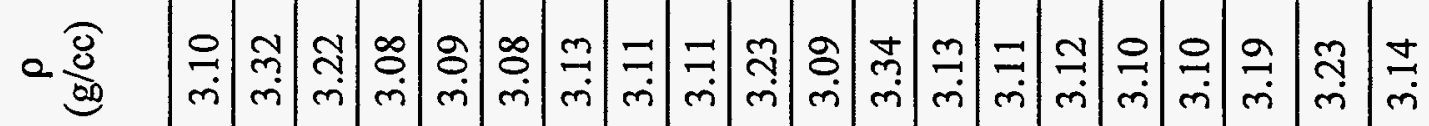

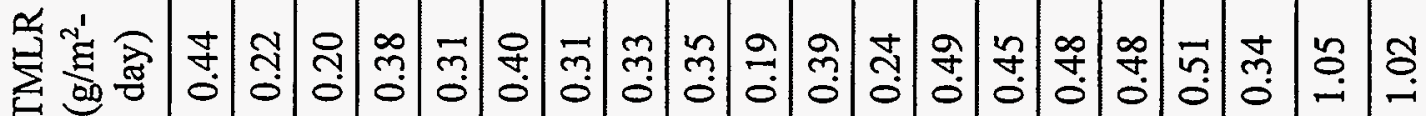

.

仓ัن

:

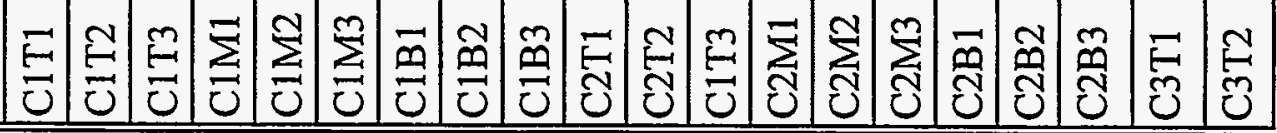




\begin{tabular}{|c|c|c|c|c|c|c|c|c|c|c|c|}
\hline 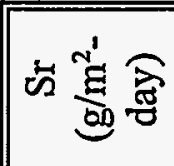 & $\frac{\tilde{x}}{2} \delta$ & & & & & & & $\begin{array}{l}c \\
\vdots\end{array}$ & $\begin{array}{c}: \\
:\end{array}$ & & $\left|\frac{\delta}{z}\right| \frac{\Sigma}{z}$ \\
\hline 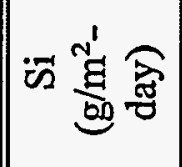 & 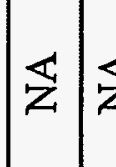 & $\frac{\pi}{2} \mid \frac{\pi}{2}$ & & & & $\stackrel{0}{\circ}$ & & & $\begin{array}{c}\text { הู } \\
3\end{array}$ & & $|\mathbb{z}| \widehat{z}$ \\
\hline 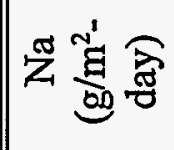 & $\left|\frac{\pi}{z}\right| \frac{s}{z}$ & $\frac{\pi}{2}$ & & & 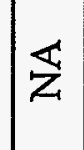 & : & & & 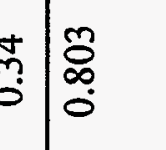 & & \\
\hline 㫷鸽 & $\approx \pi$ & $\frac{\pi}{2}$ & & & & d: & 惹 & & 走 & & $\frac{\pi}{z}$ \\
\hline & $\frac{\pi}{2}$ & $\begin{array}{l}\mathbb{z} \\
z\end{array}$ & & & & 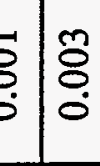 & $\mid \leq$ & $\vdots$ & 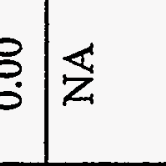 & $\overleftrightarrow{\approx}$ & $\mid \frac{\pi}{z}$ \\
\hline 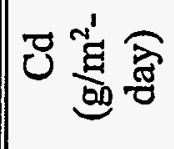 & $\left|\frac{\pi}{z}\right| \frac{\pi}{z}$ & $\mathbb{z} \mid \mathbb{z}$ & & & & 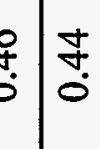 & 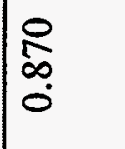 & $\because$ & s. & & \\
\hline 20. & $\widehat{z}$ & $\mathbb{z} \frac{\pi}{z}$ & & 412 & & $8:$ & & 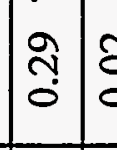 & 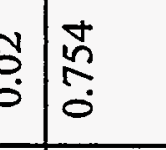 & & $\underline{z}$ \\
\hline क्रेण & $\mathbb{z} \mid \mathbb{z}$ & $\mathbb{z} \approx \mathbb{z}$ & & 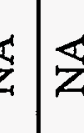 & & त् & & $\overline{0}$ & $\begin{array}{l}\qquad \\
\qquad\end{array}$ & & $\mathbb{z}$ \\
\hline ব簬高 & $\frac{\pi}{z} \frac{\pi}{z}$ & $\frac{\pi}{2} \frac{\pi}{z}$ & & $z$ & & 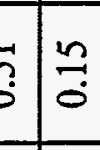 & & 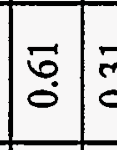 & 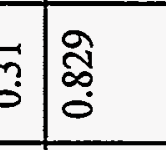 & & $\mid \frac{\tilde{z}}{2}$ \\
\hline 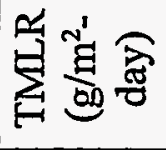 & 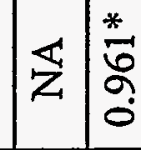 & $\begin{array}{l}0 \\
0 \\
0\end{array}$ & & & & 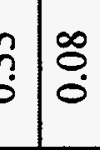 & & & 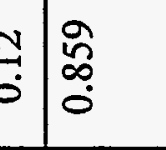 & & \\
\hline$=\sqrt{8}$ & 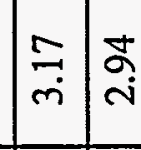 & 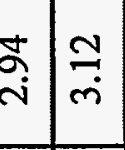 & & 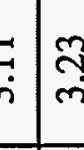 & & 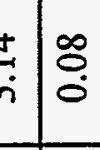 & & $\left(\begin{array}{c}\circ \\
\end{array}\right.$ & $\begin{array}{c}: \\
:\end{array}$ & & $:$ \\
\hline & & & & & & 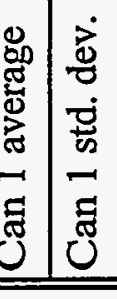 & & 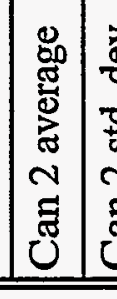 & & $\begin{array}{l}0 \\
\vdots \\
0 \\
0 \\
0 \\
0\end{array}$ & 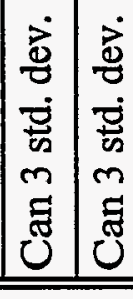 \\
\hline
\end{tabular}


Table 8

Density ( $\rho$ ), Total Mass Loss (TMLR), and Elemental Mass Loss Rates from MCC-1 Leach Tests of Samples taken from Small-Scale (1"OD x 3"tall) HIP Cans 1 and 2

\begin{tabular}{||l|l|l|c|c|c|c|c|c|c|c|c|c||}
\hline Sample & $\begin{array}{l}\text { Temp } \\
\left({ }^{\circ} \mathrm{C}\right)\end{array}$ & $\begin{array}{c}\rho \\
(\mathrm{g} / \mathrm{cc})\end{array}$ & $\begin{array}{c}\text { TMLR } \\
\left(\mathrm{g} / \mathrm{m}^{2}-\right. \\
\text { day })\end{array}$ & $\begin{array}{c}\mathrm{Al} \\
\left(\mathrm{g} / \mathrm{m}^{2}-\right. \\
\text { day })\end{array}$ & $\begin{array}{c}\mathrm{B} \\
\left(\mathrm{g} / \mathrm{m}^{2}-\right. \\
\text { day })\end{array}$ & $\begin{array}{c}\mathrm{Ca} \\
\left(\mathrm{g} / \mathrm{m}^{2}-\right. \\
\text { day })\end{array}$ & $\begin{array}{c}\mathrm{Cd} \\
\left(\mathrm{g} / \mathrm{m}^{2}-\right. \\
\text { day })\end{array}$ & $\begin{array}{c}\mathrm{Cr} \\
\left(\mathrm{g} / \mathrm{m}^{2}-\right. \\
\text { day })\end{array}$ & $\begin{array}{c}\mathrm{K} \\
\left(\mathrm{g} / \mathrm{m}^{2}-\right. \\
\text { day })\end{array}$ & $\begin{array}{c}\mathrm{Na} \\
\left(\mathrm{g} / \mathrm{m}^{2}-\right. \\
\text { day })\end{array}$ & $\begin{array}{c}\mathrm{Si} \\
\left(\mathrm{g} / \mathrm{m}^{2}-\right. \\
\text { day })\end{array}$ & $\begin{array}{c}\mathrm{Sr} \\
\left(\mathrm{g} / \mathrm{m}^{2}-\right. \\
\text { day })\end{array}$ \\
\hline \hline KV-1 & 1050 & 3.17 & 0.18 & 0.34 & 0.08 & 0.26 & 0.63 & $<0.01$ & $<0.01$ & 0.51 & 0.27 & 0.26 \\
\hline BAS-21 & 1025 & 3.11 & 0.17 & 0.31 & 0.29 & 0.24 & 0.32 & 0.52 & 0.37 & 0.46 & 0.24 & 0.11 \\
\hline BAS-22 & 1025 & 3.18 & 0.32 & 0.50 & 0.70 & 0.21 & 0.21 & 0.47 & 0.98 & 1.35 & 0.37 & 0.41 \\
\hline BAS-23 & 975 & 3.17 & 0.21 & 0.48 & 0.49 & 0.24 & 0.20 & 0.41 & 0.79 & 1.09 & 0.32 & 1.83 \\
\hline BAS-24 & 1075 & 3.15 & 0.35 & 0.84 & 0.87 & 0.14 & 0.39 & 0.98 & 1.27 & 1.83 & 0.66 & 0.17 \\
\hline BAS-25 & 1025 & 3.13 & 0.26 & 0.49 & 0.61 & 0.24 & 0.32 & 0.01 & 0.71 & 1.14 & 0.37 & 0.01 \\
\hline BAS-26 & 1025 & 3.11 & 0.27 & 0.43 & 0.40 & 0.20 & 0.45 & 0.01 & 0.64 & 0.73 & 0.36 & 0.01 \\
\hline BAS-27 & 1025 & 3.04 & 0.40 & 0.71 & 0.92 & 0.16 & 0.17 & 1.25 & 1.16 & 1.61 & 0.45 & 0.52 \\
\hline BAS-28 & 1025 & 3.15 & 0.36 & 0.90 & 1.18 & 0.16 & 0.38 & 0.52 & 1.38 & 1.89 & 0.64 & 0.33 \\
\hline BAS-29 & 1025 & 3.14 & 0.36 & 0.77 & 1.56 & 0.23 & 0.12 & 0.39 & 1.33 & 1.77 & 0.50 & 0.01 \\
\hline BAS-30 & 1025 & 3.11 & 0.40 & 0.76 & 1.22 & 0.19 & 0.13 & 0.01 & 1.27 & 1.93 & 0.47 & 0.01 \\
\hline BAS-31 & 1025 & 3.09 & 0.34 & 0.70 & 1.00 & 0.17 & 0.15 & 1.12 & 0.16 & 1.71 & 0.46 & 0.42 \\
\hline BAS-32 & 1025 & 3.12 & 0.31 & 0.85 & 1.04 & 0.17 & 0.11 & 1.18 & 1.38 & 1.87 & 0.50 & 0.42 \\
\hline
\end{tabular}

- Sample KV-1 obtained from reference (Status Report: The Glass-Ceramic Processing Flowsheet for ICPP High-Level Waste", WDBolon, JDHERZOG, AL OLSON WINCO 1090, December, 1991, pg. 13), Samples BAS-XX obtained from (Selection of a Glass-Ceramic Formulation to Immobilize Fluorinel-Sodium Calcine," B. A. Staples and H. C. Wood, June, 1994.pg 17) 


\subsection{Physical Properties}

A GrindoSonic (see Section 2.2) instrument was used to non-destructively estimate physical properties of glass-ceramic sample bars taken from the top, middle, and bottom of intermediatescale cans and for samples taken from small-scale cans. The material properties determined for glass-ceramic samples produced in intermediate and small-scale HIP cans is shown in Table 9. The Young's modulus and shear modulus of glass-ceramic material prepared in intermediatescale HIP cans was slightly higher than the glass-ceramic material prepared in small HIP cans. Also, a higher Young's modulus and shear modulus was observed in samples taken from the middle of intermediate-scale HIP cans as compared to samples taken from the top and bottom of the can.

Table 9

Physical Properties of Small and Large HIP Can Glass-Ceramic Waste Forms

\begin{tabular}{|l|l|l|l|l|l||}
\hline Sample & Type & $\begin{array}{l}\text { E } \\
(\mathrm{mpsi})\end{array}$ & $\begin{array}{l}\text { G } \\
(\mathrm{mpsi})\end{array}$ & $\mathbf{l}$ & $\begin{array}{l}\text { Density } \\
\left(\mathrm{g} / \mathrm{cm}^{3}\right)\end{array}$ \\
\hline 42B & Small HIP Can & 11.4 & 4.7 & 0.22 & 3.259 \\
\hline C1T & Large HIP Can & 12.0 & 4.9 & 0.22 & 3.206 \\
\hline C1M1 & Large HIP Can & 13.3 & 5.5 & 0.22 & 3.078 \\
\hline C1M2 & Large HIP Can & 12.2 & 5.0 & 0.22 & 2.960 \\
\hline C1B & Large HIP Can & 11.8 & 4.9 & 0.23 & 3.104 \\
\hline C2T & Large HIP Can & 11.4 & 4.6 & 0.24 & 3.259 \\
\hline C2B & 6-in $\times 12$-in & 12.0 & 4.9 & 0.23 & 3.091 \\
\hline C2M & Large HIP Can & 11.7 & 4.8 & 0.22 & 3.142 \\
\hline C3T & 4-in $\times 7$-in & 17.2 & --- & --- & 3.159 \\
\hline C3M & 4-in $\times 7$-in & 4.12 & --- & --- & 2.918 \\
\hline
\end{tabular}




\subsection{Analytical Results}

SEM micrographs prepared from samples taken from the top, middle, and bottom of intermediate-scale HIP Can 1 and 2 are shown in Figure 8 and 9 respectively. The phases identified in the micrographs include glass, cadmium (Cd), cadmium sulfide (CDs), fluorite $\left(\mathrm{CaF}_{2}\right)$, Zircon $\left(\mathrm{ZrSiO}_{4}\right)$, Zirconia $\left(\mathrm{ZrO}_{2}\right)$, sphene $\left(\mathrm{CaTiSiO}_{5}\right)$, an unknown chrome-titanate phase, and a titanate phase $\left(\mathrm{TiO}_{2}\right)$. The phases identified in glass-ceramic samples produced in intermediate-scale cans are identical to phases produced in small-scale HIP cans. ${ }^{7}$

An elemental analysis (completed on the superprobe) of representative phases of glass- ceramic material produced in Can 1 is shown in Table 10. The simulated radionuclides $\mathrm{Ce}$ and $\mathrm{Sr}$ were found principally in the glass and titanium-rich phases. Optical micrographs of glass-ceramic samples taken from the top middle and bottom of Can 1 is shown in Figure 10. The colors shown in Figure 10 are classified as follows: the glass phase is pinkish, CDs is brownish, sphene is a spear-like bluish crystal, zircon is a yellowish spear-like crystal, unreacted calcine is greenish and titanium-rich phases are black. 


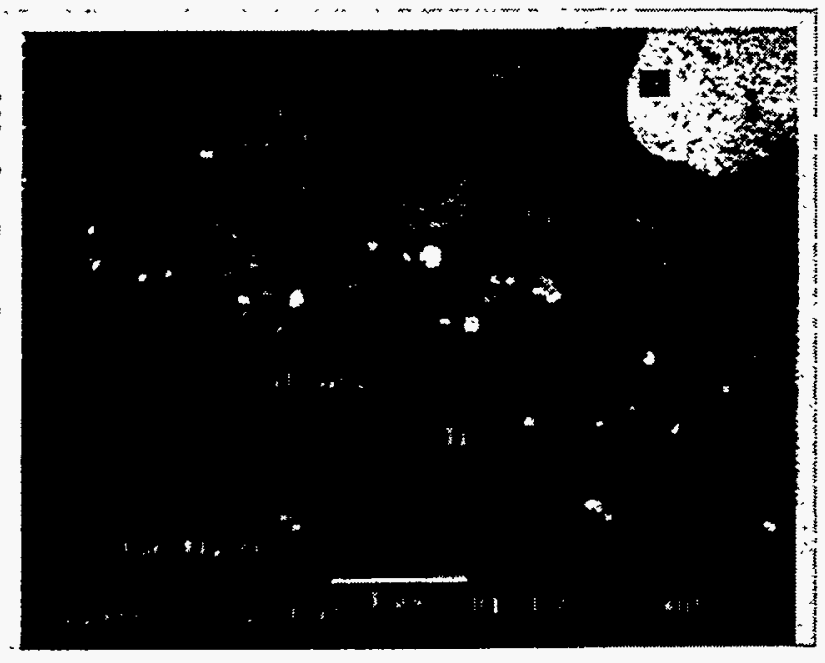

(a)

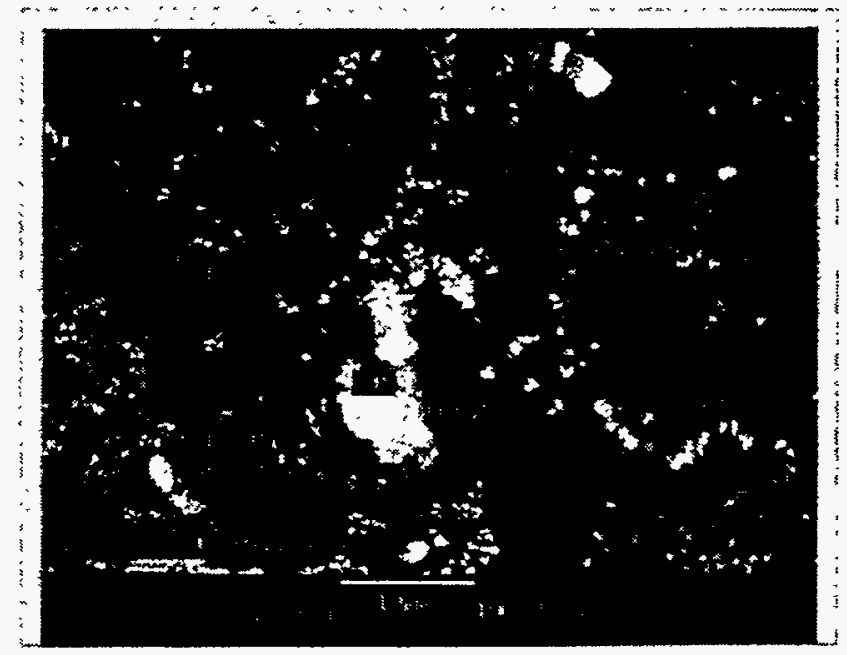

(b)

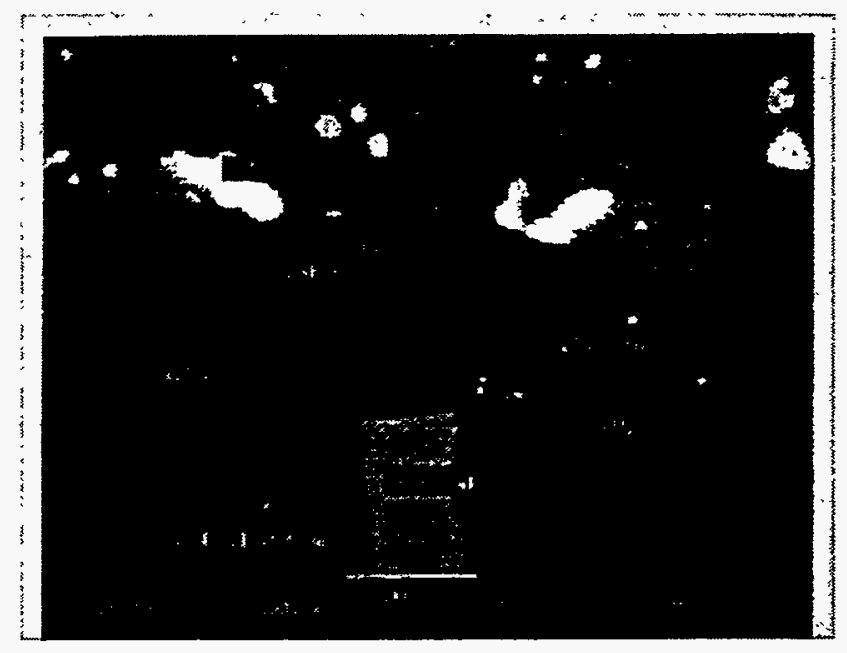

(c)

Figure 8. SEM micrographs of glass-ceramic samples taken from the (a) top, (b) middle, and (c) bottom of intermediate-scale (6"OD x 12" tall) Can 1. Phases shown include glass (darkest irregular-shaped phase), fluorite (gray, circular phase), cadmium (light, circular phase), zircon (light, rectangular phase), sphene (light, spear-like phase), and a titanium-rich phase (gray, spearlike phase precipitating from the glass). $2000 \mathrm{X}$ magnification. 


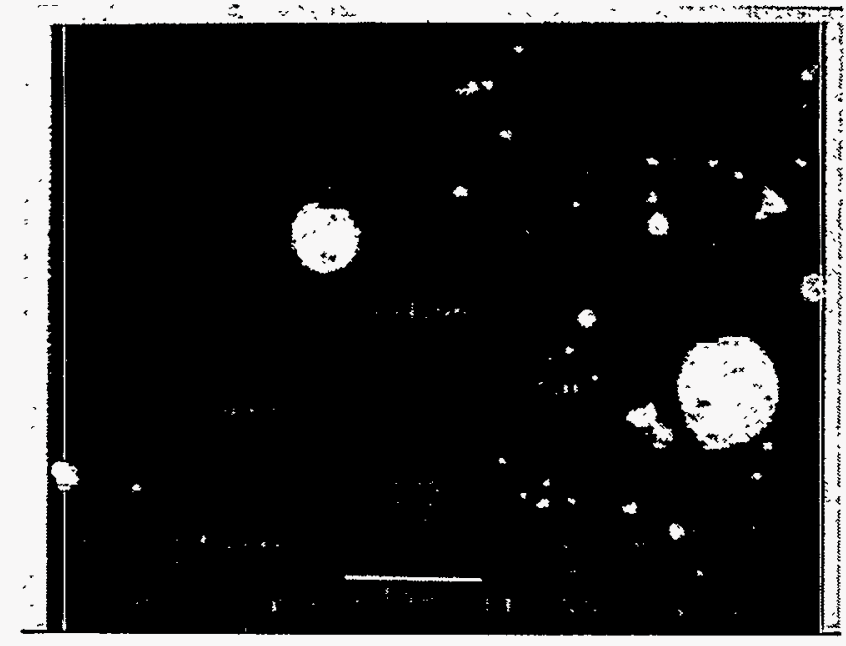

(a)

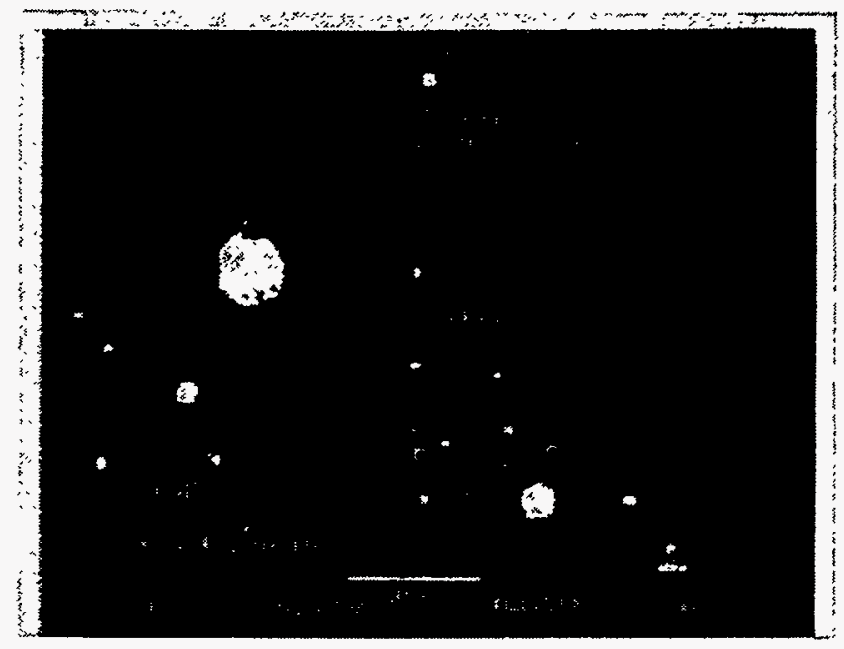

(b)

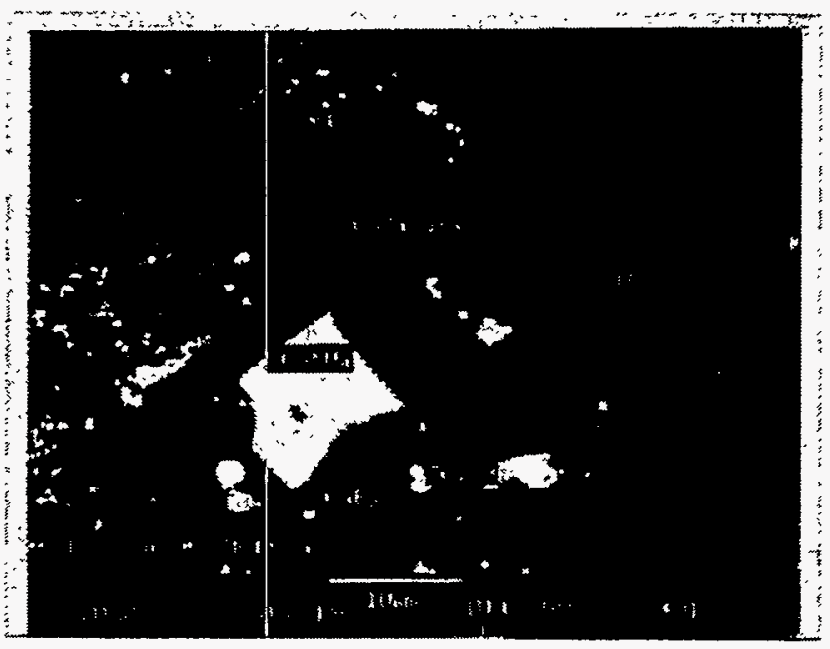

(c)

Figure 9. SEM micrographs of glass-ceramic samples taken from the (a) top, (b) middle, and (c) bottom of intermediate-scale (6"OD x 12" tall) Can 2. Phases shown include glass (darkest irregular-shaped phase), fluorite (gray, circular phase), cadmium (light, circular phase), zircon (light, rectangular phase), sphene (light, spear-like phase), and a titanium-rich phase (gray, spearlike phase precipitating from the glass). 2000X magnification. 
Table 10

Elemental Composition of Glass-Ceramic Samples Taken from Can 1

\begin{tabular}{|c|c|c|c|c|c|c|c|c|c|c|c|}
\hline Comp & Glass- $T$ & Glass - M & Glass - B & $\begin{array}{c}\text { Zircon - } \\
\mathrm{M}\end{array}$ & Zircon - B & $\begin{array}{c}\text { Sphene - } \\
\mathrm{M}\end{array}$ & $\begin{array}{c}\text { Sphene - } \\
\text { B }\end{array}$ & $\begin{array}{c}\text { Fluorite - } \\
\mathrm{M} \\
\end{array}$ & $\begin{array}{c}\text { Fluorite - } \\
\text { B }\end{array}$ & $|\mathrm{Cr}-\mathrm{Ti}-\mathrm{M}|$ & $\mathrm{Ti}-\mathrm{M}$ \\
\hline $\mathrm{Al}_{2} \mathrm{O}_{3}$ & 17.98 & 16.81 & 17.83 & 0.06 & 0.13 & 1.04 & 1.02 & 17.83 & 0.02 & 16.81 & 0.56 \\
\hline $\mathrm{B}_{2} \mathrm{O}_{3}$ & 9.52 & 10.55 & 9.76 & 0.64 & 0.61 & 0.86 & 0.85 & 9.76 & 0.78 & 10.55 & 0.46 \\
\hline $\mathrm{CaO}$ & 3.65 & 8.56 & 8.95 & 0.14 & 0.17 & 24.05 & 32.14 & 8.95 & 0.00 & 8.56 & 0.59 \\
\hline $\mathrm{CeO}$ & 0.08 & 0.08 & 0.10 & 0.57 & 0.12 & 0.20 & 0.21 & 0.10 & 0.07 & 0.08 & 0.43 \\
\hline $\mathrm{CdO}$ & 0.01 & 0.00 & 0.01 & 0.00 & 0.05 & 0.01 & 0.01 & 0.01 & 0.05 & 0.00 & 0.01 \\
\hline $\mathrm{Cs}_{2} \mathrm{O}$ & 0.00 & 0.00 & 0.00 & 0.00 & 0.00 & 0.00 & 0.00 & 0.00 & 0.00 & 0.00 & 0.00 \\
\hline $\mathrm{Cr}_{2} \mathrm{O}_{3}$ & 0.37 & 0.45 & 0.37 & 0.04 & 0.06 & 0.72 & 1.21 & 0.37 & 0.06 & 0.45 & 3.45 \\
\hline $\mathrm{FeO}$ & 0.00 & 0.00 & 0.01 & 0.00 & 0.00 & 0.00 & 0.00 & 0.01 & 0.00 & 0.00 & 0.01 \\
\hline $\mathrm{K}_{2} \mathrm{O}$ & 0.19 & 0.22 & 0.21 & 0.03 & 0.00 & 0.03 & 0.00 & 0.21 & 0.00 & 0.22 & 0.02 \\
\hline $\mathrm{MgO}$ & 0.38 & 0.40 & 0.39 & 0.01 & 0.02 & 0.03 & 0.06 & 0.39 & 0.03 & 0.40 & 0.11 \\
\hline $\mathrm{Na}_{2} \mathrm{O}$ & 0.19 & 0.60 & 0.42 & 0.00 & 0.00 & 0.13 & 0.36 & 0.42 & 0.23 & 0.60 & 0.23 \\
\hline $\mathrm{P}_{2} \mathrm{O}_{5}$ & 0.02 & 0.00 & 0.01 & 0.00 & 0.00 & 0.03 & 0.05 & 0.01 & 0.05 & 0.00 & 0.02 \\
\hline $\mathrm{SiO}_{2}$ & 57.90 & 47.66 & 48.20 & 31.18 & 31.25 & 28.65 & 34.17 & 48.20 & 0.18 & 47.66 & 0.24 \\
\hline $\mathrm{TiO}_{2}$ & 2.03 & 3.91 & 3.74 & 0.93 & 1.01 & 33.93 & 28.01 & 3.74 & 0.06 & 3.91 & 92.71 \\
\hline SrO & 0.31 & 0.28 & 0.29 & 0.64 & 0.65 & 0.19 & 0.15 & 0.29 & 0.00 & 0.28 & 0.00 \\
\hline $\mathrm{ZrO}_{2}$ & 2.83 & 4.06 & 3.91 & 65.77 & 65.92 & 5.53 & 1.72 & 3.91 & 0.03 & 4.06 & 1.15 \\
\hline 0 & 0.00 & 0.00 & 0.00 & 0.00 & 0.00 & 0.00 & 0.00 & 0.00 & 0.00 & 0.00 & 0.00 \\
\hline$S$ & 0.14 & 0.17 & 0.20 & 0.00 & 0.00 & 0.00 & 0.00 & 0.20 & 0.01 & 0.17 & 0.00 \\
\hline $\mathrm{Cl}$ & 0.25 & 0.31 & 0.22 & 0.01 & 0.00 & 0.00 & 0.00 & 0.22 & 0.02 & 0.31 & 0.02 \\
\hline$F$ & 2.21 & 3.12 & 2.84 & 0.00 & 0.00 & 2.23 & 0.02 & 2.84 & 47.92 & 3.12 & 0.00 \\
\hline $\mathrm{CaF}_{2}$ & 4.54 & 6.41 & 5.83 & 0.00 & 0.00 & 4.58 & 0.05 & 5.83 & 98.45 & 6.41 & 0.00 \\
\hline Total & 100.00 & 100.00 & 100.00 & 100.00 & 100.00 & 100.00 & 100.00 & 100.00 & 100.00 & 100.00 & 100.00 \\
\hline
\end{tabular}




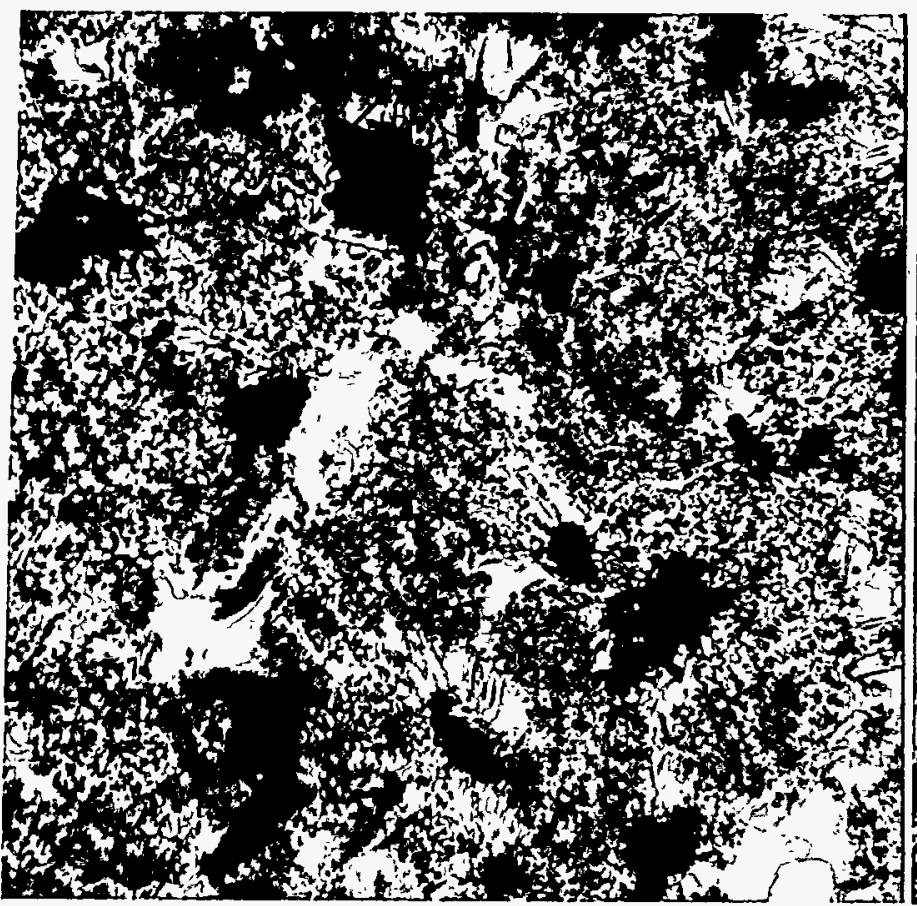

(a)

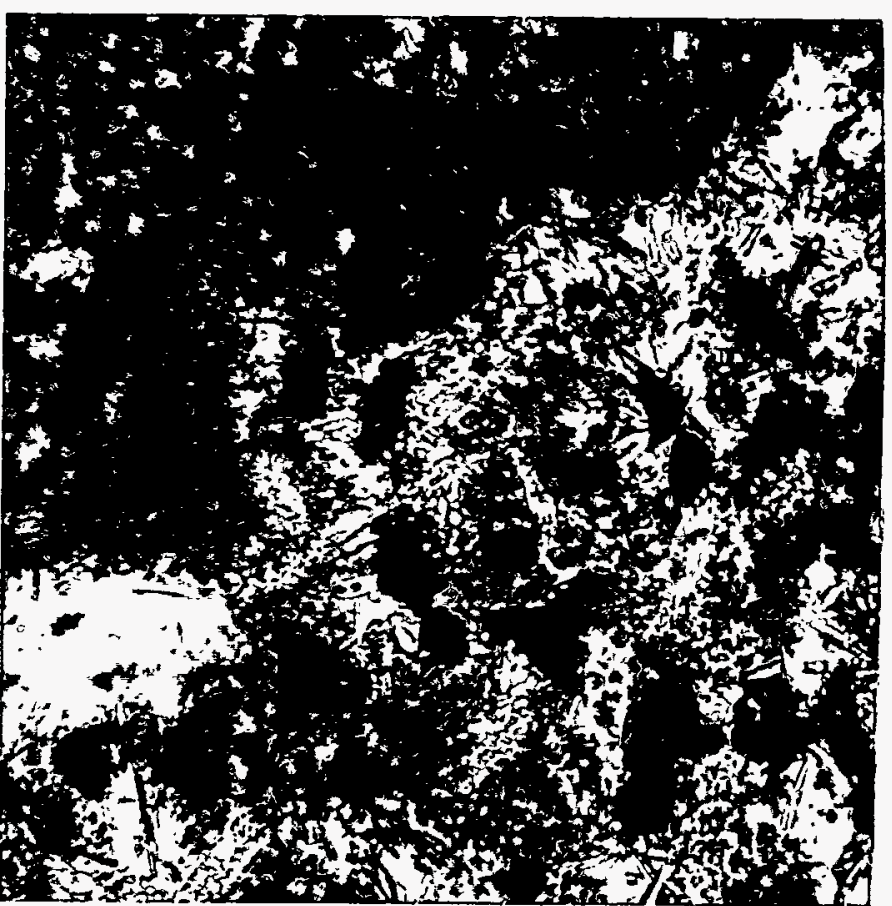

(b)

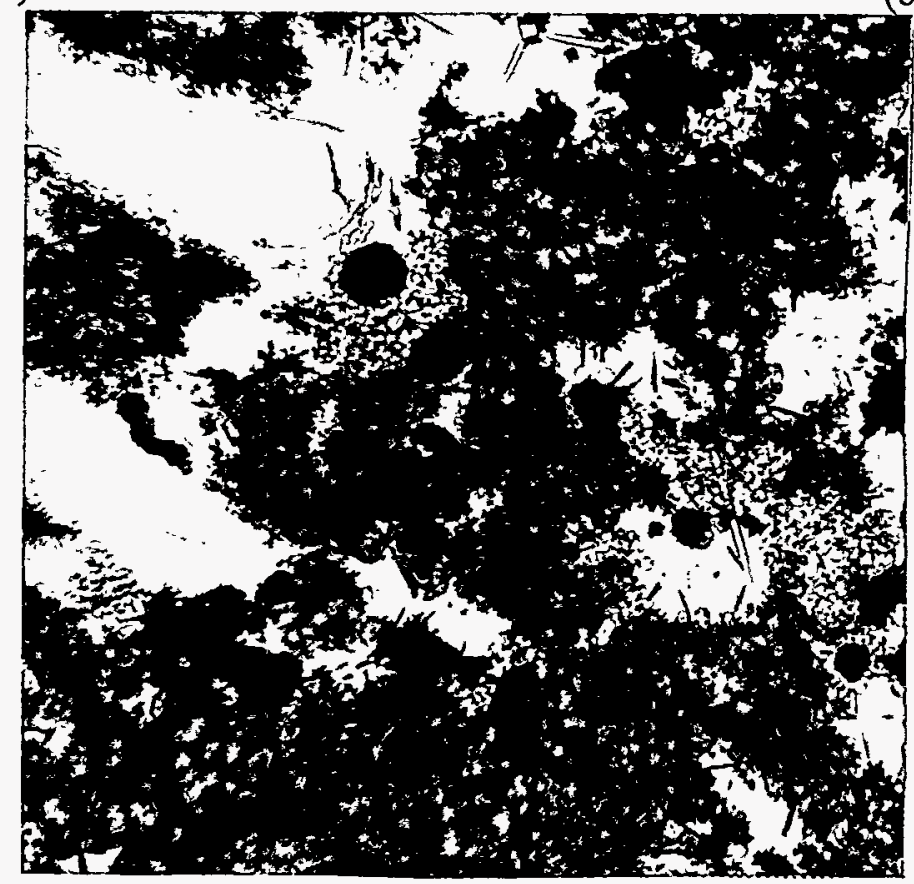

(c)

Figure 10. Optical microscope photographs of glass-ceramic samples taken from the (a) top, (b) middle, and (c) bottom of the intermediate-scale (6-in OD x 12-in tall) hot isostatic press (HIP) Can 1. Phases shown in the pictures include glass (pink), titanium (black), unreacted calcine particles (green), zircon (spear-like), sphene (spear-like), and CDs (brown edges of the black phase - see ' $c$ ' above). 200X magnification. 


\section{DISCUSSION}

A discussion of intermediate-scale HIP can experimental results presented in the following section. This discussion includes eddy-current sensor measurements of Can 3 and 4; scale-up trends; and a discussion of density, leach resistance, physical properties, and microstructure of glass-ceramic material produced in intermediate-scale cans compared to material produced in small-scale cans.

\subsection{Eddy-Current Sensor Measurements}

Based on the eddy-current sensor measurements of $\operatorname{Can} 3$ and 4, densification of glass-ceramic material occurs rapidly at approximately $700^{\circ} \mathrm{C}$. At this temperature, the can's metal cladding provides a significant resistance to deformation and buckles at predictable locations. As the temperature and pressure increase during the HIP cycle, the buckles observed at $700^{\circ} \mathrm{C}$ become more pronounced. This buckling effect was observed during the HIPping of Can 3 . When Can 3 was removed from the HIP after the partial densification (Can 3 was HIPped at $550^{\circ} \mathrm{C}$ ), a minor deformation (buckling) was noted in the can wall at the seam weld. Inspection of Can 3 after HIPping at $1050^{\circ} \mathrm{C}$ revealed that the deformation at the seam weld had increased. Careful can design is required to properly design a HIP can and avoid the can buckling problem.

\subsection{Overall Packing Efficiency}

The $E_{\text {op }}$ calculated for Can 1 and 2 was 13 to $14 \%$ higher than similarly configured small-scale cans (see Table 6). The major scale-up effect on $\mathrm{E}_{\text {op }}$ was a lower proportional volume of stainless steel cladding material in larger cans ( 0.09$)$ compared to smaller cans $(0.31)$. Minor scale-up effects on $E_{o p}$ include: 1) higher pre-HIPping powder density in intermediate-scale cans $(1.78 \mathrm{~g} / \mathrm{cc})$ compared to smaller-scale cans $(1.60 \mathrm{~g} / \mathrm{cc})$ and 2$)$ increased can wall rigidness in thicker-walled intermediate-scale cans. 
The $E_{o p}$ calculated for Can 3 and 4 was nearly the same as observed in small-scale testing. The lower $E_{\text {op }}$ for the 4-in OD x 7-in tall cans (compared to 6-in OD $\times 12$-in tall cans) is due to the deformation pattern of the smaller cans. The intermediate-scale can side walls were rolled into a cylinder from stainless steel sheet and seam welded to form a cylinder. The seam of the 4-in OD $\mathrm{x} 7$-in tall cans was stiff enough to resist deformation at low temperatures and retained its original length after the HIP process. Small-scale cans are made from seamless tubing and do not exhibit this behavior. The deformation pattern observed in 4-in OD x 7-in tall cans is not expected to be repeated in larger-scale cans based on the deformation pattern of 6-in OD x 12-in tall cans. During HIPping, the weld seam in the 6-in OD x 12-in tall can was pliable and did not resist deformation. Hence, the prediction of production-scale $\mathrm{E}_{\mathrm{op}}$ is based on small-scale and 6-in OD x 12-in tall HIP can tests only.

The cladding volume in the production-scale can would be approximately $3 \%$ of the total can volume. The production-scale HIP can $\mathrm{E}_{\text {op }}$ would be approximately $64 \%$ based on the $\mathrm{E}_{\text {op }}$ calculated for small- and intermediate-scale tests as shown in Figure 11. The $\mathrm{E}_{\mathrm{op}}$ of productionscale HIP cans may be increased further by optimizing the HIP can geometry and/or the HIP cycle. For example, the $E_{\text {op }}$ of a small-scale can designed and tested by the Australian Nuclear Science and Technology Organisation (ANSTO) was $75 \%$ as compared to $45 \%$ for a rightcircular cylinder can geometry. A picture of the ANSTO can before and after HIPping is shown in Figure 12. Further modifications to the HIP can geometry would further increase the $E_{o p}$. Improvements of the $\mathrm{E}_{\mathrm{op}}$ from HIP cycle optimization are theoretically possible but have not been demonstrated. 


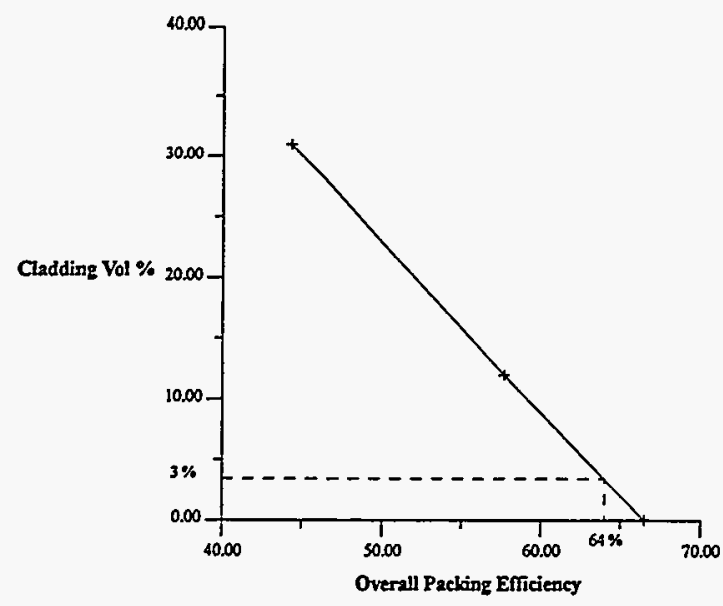

Figure 11. Plot of overall packing efficiency $\left(\mathrm{E}_{\mathrm{op}}\right)$ as a function of cladding volume $\%$. The dotted line represents the expected $\mathrm{E}_{\mathrm{op}}$ of a can with a cladding volume of $3 \%$.

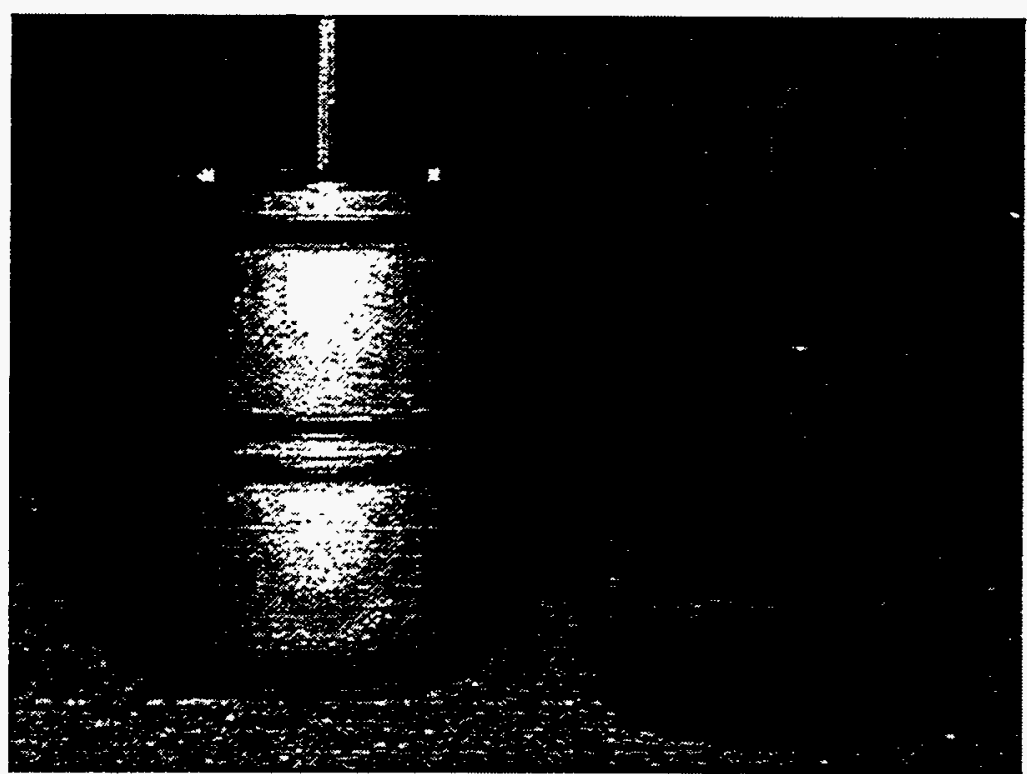

Figure 12. ANSTO-designed HIP can. Photograph of can before and after HIPping at $1050^{\circ} \mathrm{C}$ and 20,000 psi. 


\subsection{Can Slicing}

A sulfur odor (likely $\mathrm{SO}_{2}$ ) was detected in the ambient air during the slicing operation of Can 1 . Modification of the can preparation and sealing procedure would decrease the amount of $\mathrm{SO}_{2}$ present in the glass-ceramic since $\mathrm{SO}_{2}$ was not detected during the $\mathrm{Can} 2$ and 3 slicing operation. The bakeout procedure completed on Can $1\left(600^{\circ} \mathrm{C}\right.$ for 36 hours) served to remove residual $\mathrm{NO}_{\mathrm{x}}$, $\mathrm{CO}_{\mathrm{x}}$, and $\mathrm{H}_{2} \mathrm{O}$; but the procedure may have caused oxidation of the metal reductant (Ti metal powder). Hence, $\mathrm{S}^{+4}$ was not reduced to $\mathrm{S}^{+2}$ and $\mathrm{CDs}$ (or other stable sulfide) did not form during the HIP process. It is anticipated that a lower-temperature bake-out procedure as used with Can 3 and 4 and heat treatment of calcine before calcine/frit blending would eliminate the formation of $\mathrm{SO}_{2}$ in the glass-ceramic waste form.

$\mathrm{X}$-ray analysis of HIP Can 2 completed before slicing showed may cracks. The cracks arise from two principal sources: 1) Ti-based glass-ceramics are brittle compared to other glass-ceramic formulations and 2) temperature differences and thermal stresses in the glass-ceramic arising from cooling. Additional research and development would be required to optimize the Ti added to the waste form (to reduce brittleness) and the cooling cycle (to reduce thermal stress in the can) in an effort to produce a monolithic glass-ceramic waste form.

\subsection{Density Measurements and MCC-1 Leach Test}

The Ti-based formulation utilized in these experiments was developed for fluorinel-sodium calcine. Immobilization of other calcine types with this formulation was not recommended. However, the Ti-based formulation appeared to adequately immobilize both fluorinel-sodium and a 50/50 blend of fluorinel-sodium/zirconia-sodium calcine in intermediate-scale tests. Hence, the Ti-formulation does not appear to be sensitive to minor compositional differences.

The glass-ceramic leach resistance (as measured by the total mass loss) was not affected by sample location (i.e., the leach resistance was relatively constant throughout the can) as leach 
resistance data exhibited a normal distribution and a relatively low variance (see Table 7). Quality of calcine/frit mixing, calcine/frit particle size at various locations within the can, and uncertainty in spectrochemical analyses, may account for the variability.

A Shapiro-Wilke statistical test was applied to the experimental data collected in the intermediate-scale HIP can tests. Based on the statistical test, the data are normally distributed. A normal distribution and small variance infers that differences in data may be attributable to experimental error and not to an underlying mechanism. An underlying mechanism may be suspected in cases of a normal distribution and a large variance. The large variance and normal distribution of the leach rate of glass-forming elements ( $\mathrm{Al}, \mathrm{B}, \mathrm{K}, \mathrm{Na}$, and $\mathrm{Si}$ ) indicates differences in glass-phase durability. Also, a large variance in Cd leachability indicates $\mathrm{Cd}$ mobility within the HIP can at HIPping temperatures. Volatilized Cd is capable of diffusing through the glass-ceramic material at various rates depending on the glass and crystalline phases present during the HIP process. Where the $\mathrm{Cd}$ is more concentrated, the normalized elemental mass loss rate is greater. Cd mobility also has been observed in small-scale HIP can tests. ${ }^{8}$ On the other hand, the small variance and normal distribution of $\mathrm{Ca}$ leach rate data is indicative of no underlying cause or mechanism. Differences in Ca mass loss data are due to experimental uncertainty. Ca is found mainly in the crystalline phase and seems to be well dispersed throughout the glass-ceramic material.

The density and leach resistance (as determined by the 14-day MCC-1 leach test) of the glassceramic material produced in intermediate-scale tests (see Table 7) was similar to material produced in small-scale tests (see Table 8). The total mass loss rate of glass-ceramic material produced in intermediate-scale tests and in small-scale tests was below $1 \mathrm{~g} / \mathrm{m}^{2}$ day for nearly all samples. Hence, little scale-up effect is observed in glass-ceramic leach resistance.

\subsection{Physical Properties}

The Young's modulus, shear modulus, and Poisson's ratio of glass-ceramic samples produced in intermediate-scale Can 1 and 2 varied from 11.4 to $13.3 \mathrm{mpsi}, 4.6$ to $5.5 \mathrm{mpsi}$, and 0.22 to 0.24 
respectively (see Table 9). The GrindoSonic instrument was not able to reproducibly estimate the physical properties of samples produced in Can 3 and 4 due to excessive cracking. The physical properties of material produced in small-scale cans were slightly lower than the properties of glass-ceramic material produced in intermediate-scale cans (see Table 9, sample 42B). These higher property values are thought to be due to the smaller relative thickness (ratio between HIP can lid thickness to can overall length) of the larger cans. Hence, there appears to be no adverse scale-up effect on glass-ceramic physical properties. Also, the physical properties appear to vary randomly within the can. However, additional glass-ceramic physical property data are required to verify this randomness.

\subsection{Microstructure}

One general trend was observed by studying SEM and optical micrographs of the glass-ceramic material produced in Can 1 and 2 (see Figure 8-10): the glass phase appears to become more dispersed as the sample position moves from the bottom to the top of the HIP can. This glassphase dispersion is due two effects: (1) differences in processing time at the required temperature (i.e., the can top could have reached HIPping temperature before the middle and bottom and as a result could have been exposed to higher temperatures for a longer period of time and (2) differences in reactant particle size (i.e., the larger particles settled on the bottom of the HIP can during filling and vibrational pre-compaction). 


\section{CONCLUSIONS AND RECOMMENDATIONS}

Based on the results presented in this report, the following conclusions are made:

1- There is no significant difference between the properties of the glass-ceramic material produced in intermediate- and small-scale HIP cans. No major scale-up problems were indicated.

2- Glass-ceramic properties (leach resistance, density, Young's modulus, shear modulus, Poisson's ratio) do not vary significantly within the intermediate-scale HIP can.

3- A suitable glass-ceramic material can be produced in a 6-in OD x 12-in tall HIP can using a pressure, temperature, and soak time of $1050^{\circ} \mathrm{C}, 10,000 \mathrm{psi}$, and four hours respectively. No significant scale-up problems were indicated.

4- Most can shrinkage and deformation occurs at a temperature of approximately $700^{\circ} \mathrm{C}$. Only minor shrinkage and deformation occurs at temperatures greater than $700^{\circ} \mathrm{C}$.

5- The quality of calcine and frit mixing did not adversely affect glass-ceramic. waste form properties on the intermediate scale. No significant scale-up problems were indicated.

6- The $\mathrm{E}_{\mathrm{op}}$ increases as the HIP can size increases.

7- Computer modeling would serve to reduce the number of experiments required to develop a suitable full-scale HIP can and to optimize the HIP cycle.

8- Optimization of the HIP can geometry and the HIP cycle would increase the $\mathrm{E}_{\mathrm{op}}$. 
Based on the results and conclusions presented in this report, the following recommendations are made:

1- The thermal and physical properties of the calcine/frit mixture during HIPping must be accurately determined.

2- Develop a computer model to accurately predict the final HIP can shape based on the preHIP can geometry, the fill density of the calcine/frit mixture, and the HIP soak time, temperature, and pressure.

3- Test an intermediate-scale ANSTO-designed can to determine if a larger-scale ANSTO can would produce a higher $\mathrm{E}_{\mathrm{op}}$. 


\section{REFERENCES}

1- J. E. Mendel (editor), Nuclear Waste Materials Handbook: Test Methods, DOE/TIC11400, Sept. 1983.

2- B. A. Staples and H. C. Wood, Selection of a Glass-Ceramic Formulation to Immobilize Fluorinel-Sodium Calcine. INEL-95/0041, December 1994.

3- $\quad$ Personal with J. LaGoy, IMT, September 1993.

4- Personal communications with T. F. Zahrah, BDM Federal, October, 1994.

5- $\quad$ Shapiro, S. S. and Wilke, M. B., An Analysis of Variance Test for Normality (Complete Samples), Biometrika (1065), 52, 3 and 4, pg. 591-611.

6- Personal communications with L. O. Nelson and W. D. St. Michel, March, 1994.

7- $\quad$ K. Vinjamuri, et. al., Effect of Aluminum and Silicon Reactants and Process Parameters on Glass-Ceramic Waste Form Characteristics for Immobilization of High-Level Fluorinel/Sodium Calcined Waste, WINCO-1133, June 1993.

8- Personal communications with B. A. Staples, March, 1995.

\section{DISCLAIMER}

This report was prepared as an account of work sponsored by an agency of the United States Government. Neither the United States Government nor any agency thereof, nor any of their employees, makes any warranty, express or implied, or assumes any legal liability or responsibility for the accuracy, completeness, or usefulness of any information, apparatus, product, or process disclosed, or represents that its use would not infringe privately owned rights. Reference herein to any specific commercial product, process, or service by trade name, trademark, manufacturer, or otherwise does not necessarily constitute or imply its endorsement, recommendation, or favoring by the United States Government or any agency thereof. The views and opinions of authors expressed herein do not necessarily state or reflect those of the United States Government or any agency thereof. 